\title{
Investors' evaluations of price-increase preannouncements $\frac{\hbar}{\zeta}$
}

\author{
Leon Gim Lim ${ }^{\mathrm{a}}$, Kapil R. Tuli b,*, Marnik G. Dekimpe ${ }^{\mathrm{a}, \mathrm{c}}$ \\ a Tilburg School of Economics and Management, Tilburg University, Netherlands \\ ${ }^{\mathrm{b}}$ Lee Kong Chian School of Business, Singapore Management University, Singapore \\ c KU Leuven, Belgium
}

\section{A R T I C L E I N F O}

\section{Article history:}

First received on June 22, 2017 and was

under review for $41 / 2$ months

Available online $\mathrm{xxxx}$

Senior editor: Koen H. Pauwels

Keywords:

Price increase

Preannouncement

Event study

Abnormal returns

Marketing-finance interface

\begin{abstract}
A B S T R A C T
Several firms preannounce their price increases with the expectation that such announcements will be evaluated favorably by investors. However, little is known about the actual effect they have on shareholder value. Accordingly, the authors present the first systematic empirical examination of investors' evaluations of 274 price-increase preannouncements (PIPs). Results show that whereas the average increase in abnormal returns following a PIP is $0.51 \%$, almost $41 \%$ of the PIPs result in negative abnormal returns. To explore this heterogeneity, the authors propose a conceptual framework that focuses on three key pieces of information that investors can use when evaluating a PIP: information on the nature (time to implementation and magnitude) of the preannounced price increase, the stated attribution for the preannounced price increase (demand and/or cost based), and information on prior PIP occurrences by the firm and its competitors. Results indicate that PIPs with greater time to implementation, higher own precedence and greater competitive precedence result in lower abnormal returns, while PIPs with higher magnitude and PIPs with an explicit demand attribution result in greater abnormal returns.
\end{abstract}

(c) 2018 Published by Elsevier B.V.

Price increases are widely viewed as one of the most effective marketing instruments to increase profits (Meehan, Davenport, \& Kahlon, 2012). Consulting and popular-press reports as well as industry experts frequently underscore the importance of price increases. For example, Deloitte Consulting reports that the effect of a price increase on profits is 4 times that of other initiatives (Hayes \& Singh, 2013). McKinsey \& Company reports that a 1\% increase in product price can boost the operating profits of a typical Global 1200 firm by 8.70\% (Baker, Marn, \& Zawada, 2010). The investment community also endorses the importance of price increases. Warren Buffet, for example, suggests that the ability to raise prices is investors' "single most important decision in evaluating a business" (see Frye \& Campbell, 2011, p. 1 for the full statement). Similarly, Reuters identifies a firm's ability to raise prices as the key concern for investors in 2017 (Subhedar \& Rees, 2017).

Against this background, it is not surprising that several firms publicly announce their price increases ahead of their actual implementation to signal to investors their ability and willingness to do so (Calantone \& Schatzel, 2000). For example, during 2010-2014, Starbucks made 10 price-increase preannouncements (PIPs), J.M. Smucker made 7 PIPs, while Peet's Coffee made

\footnotetext{
th This article is based on a chapter of the first author's dissertation at Singapore Management University. Part of this article was written while the third author was visiting Singapore Management University. The authors thank Russ Winer and seminar participants at Bocconi University, Singapore Management University, Tilburg University, University of Queensland, the $30^{\text {th }}$ EMAC Doctoral Colloquium, the $44^{\text {th }}$ EMAC Annual Conference, the $37^{\text {th }}$ and $38^{\text {th }}$ ISMS Marketing Science Conferences for several useful comments.

* Corresponding author.

E-mail addresses: l.g.lim@tilburguniversity.edu (L.G. Lim), kapilrtuli@smu.edu.sg (K.R. Tuli), m.g.dekimpe@tilburguniversity.edu. (M.G. Dekimpe).
} 
just one such preannouncement. Analysts tend to view a PIP as a valuable signal as it communicates potential future earnings to investors, and allows customers to make budgetary adjustments (Marn, Roegner, \& Zawada, 2004; Smith, 2011). A PIP can also act as an important competitive signal that may well influence competitors' subsequent pricing decisions (Heil \& Langvardt, 1994; Prabhu \& Stewart, 2001).

Anecdotal evidence, however, shows that investors do not always share a unanimous positive view about PIPs. For example, when J.M. Smucker preannounced a price increase 9 days before its implementation in February 2011 (J.M. Smucker Company, 2011), it resulted in an abnormal increase of $0.76 \%$ in its stock price. ${ }^{1}$ However, when it preannounced another price increase almost 2 months before its implementation in September 2011 (Ziobro, 2011), its stock price had an abnormal decrease of 0.40\%. Similarly, when Starbucks made a preannouncement of a 1\% increase in its prices in June 2013 (Kavilanz, 2013 ), it resulted in an abnormal decrease of $0.72 \%$ in its stock price. This decrease stands in stark contrast to the $4.5 \%$ price increase that was preannounced in June 2014 (Ausick, 2014), where its stock price experienced an abnormal increase of $1.85 \%$.

Given the oft-mentioned importance, combined with the contradictory anecdotal evidence, it is surprising that there is no systematic examination of investors' evaluations of a PIP. Accordingly, we draw on multiple secondary data sources to present the first large-scale empirical study of investors' evaluations of PIPs. Using an event-study approach, we measure investors' evaluations by calculating the abnormal returns following 274 PIPs between 2010 and 2014. We find that, on average, a PIP results in abnormal returns of $0.51 \%$. There is, however, significant underlying heterogeneity, as almost $41 \%$ of the PIPs result in negative abnormal returns. Therefore, we develop a conceptual framework to identify conditions under which investors will react more or less positively (negatively) to a PIP. In doing so, we respond to recent calls for more research to examine investors' evaluations of a firm's pricing decisions (Edeling \& Fischer, 2016, p. 533), and complement existing studies on price increases that almost exclusively examine customer reactions (Homburg, Hoyer, \& Koschate, 2005; Homburg, Koschate, \& Totzek, 2010).

Following the announcement of an upcoming price increase, investors may decide to buy or sell stock, a decision that depends on the performance (cash-flow) implications they expect that this increase will entail and, relatedly, on the reasons they think the firm may have to not only increase its prices, but to also preannounce that increase. These performance implications, in turn, are likely to be a function of the reactions of both customers and competitors. Indeed, customers may remain loyal to the brand (in which case a higher per-unit margin on a comparable sales volume could be obtained), or switch to cheaper alternatives (in which case the total revenues may even decrease). Similarly, competitors may either mimic the increase, which would mitigate any market-share losses, or maintain (and even decrease) their own price to improve their competitive position. Relatedly, the firm may raise its prices because of higher demand and a strong belief that its customers will stick with the brand despite the higher prices (which could be labelled a demand-dominant motivation). Alternatively, the firm could preannounce the price increase because it expects its competitors to follow, which would cause the average price (and profit margin) in the industry to increase (a setting that could be labelled competitor driven), or it may explicitly communicate that its costs are/have been rising, in which case the price increase is meant to pass on some of this cost increase to its consumers (a cost-based scenario). Or maybe the firm is just unsure about the price sensitivity of its customer base and uses the preannouncement as a price sensitivity probing mechanism.

Unfortunately, neither the customer and competitive reactions nor the underlying reasons for the price increase are known to investors at the time of the preannouncement. Because of that, investors have to infer these latent variables from information that is available and observed at that time. We postulate that investors are likely to draw such inferences from three key drivers of a PIP. First, we posit that investors will take information on the implementation of the preannounced price change into account, i.e., when it will become effective and the extent of the increase (i.e., implementation information). Second, investors can consider whether an explicit reason for the increase is offered in the announcement (i.e., attribution), and if so, whether the price change is attributed to an increase in demand and/or to an increase in the underlying costs. Finally, investors' evaluations of a PIP are likely to also be affected by prior PIP occurrences by the firm and/or its competitors (i.e., precedence).

Results provide strong support for the conceptual framework. Consistent with our emphasis on implementation information, we find that time to implementation has a significant negative impact on abnormal returns. In contrast, magnitude has a significant positive impact. Underscoring the importance of attribution, we find that a PIP is likely to result in a significant positive effect on abnormal returns if a firm provides a demand attribution. Results also support expectations about PIP precedence by both the focal firm and its competitors. Specifically, higher PIP precedence by the firm has a significant negative effect on abnormal returns. In addition, we find a significant negative effect of competitive precedence on abnormal returns following a PIP. Taken together, the results present a nuanced picture that enables senior managers to identify conditions under which PIPs are more likely to be evaluated (un)favorably by investors.

\section{Conceptual framework}

Price changes are an important facet of a firms' marketing strategy. Firms can decide to increase or decrease their prices in response to changing circumstances ranging from adjustments in consumer demand and competitive imperatives (Prabhu \& Stewart, 2001) to factors affecting its operations such as input prices (Homburg et al., 2005). Interestingly, while publicly-listed firms frequently make PIPs, they very rarely (if ever) announce upcoming price decreases. ${ }^{2}$ As such, we focus on the former.

\footnotetext{
1 An abnormal increase in stock price is an increase in the stock price that is not predicted by taking into consideration fundamental financial factors.

2 In fact, a careful search of pricing related announcements by publicly-listed firms in the calendar year 2014 did not yield a single price decrease announcement.
} 


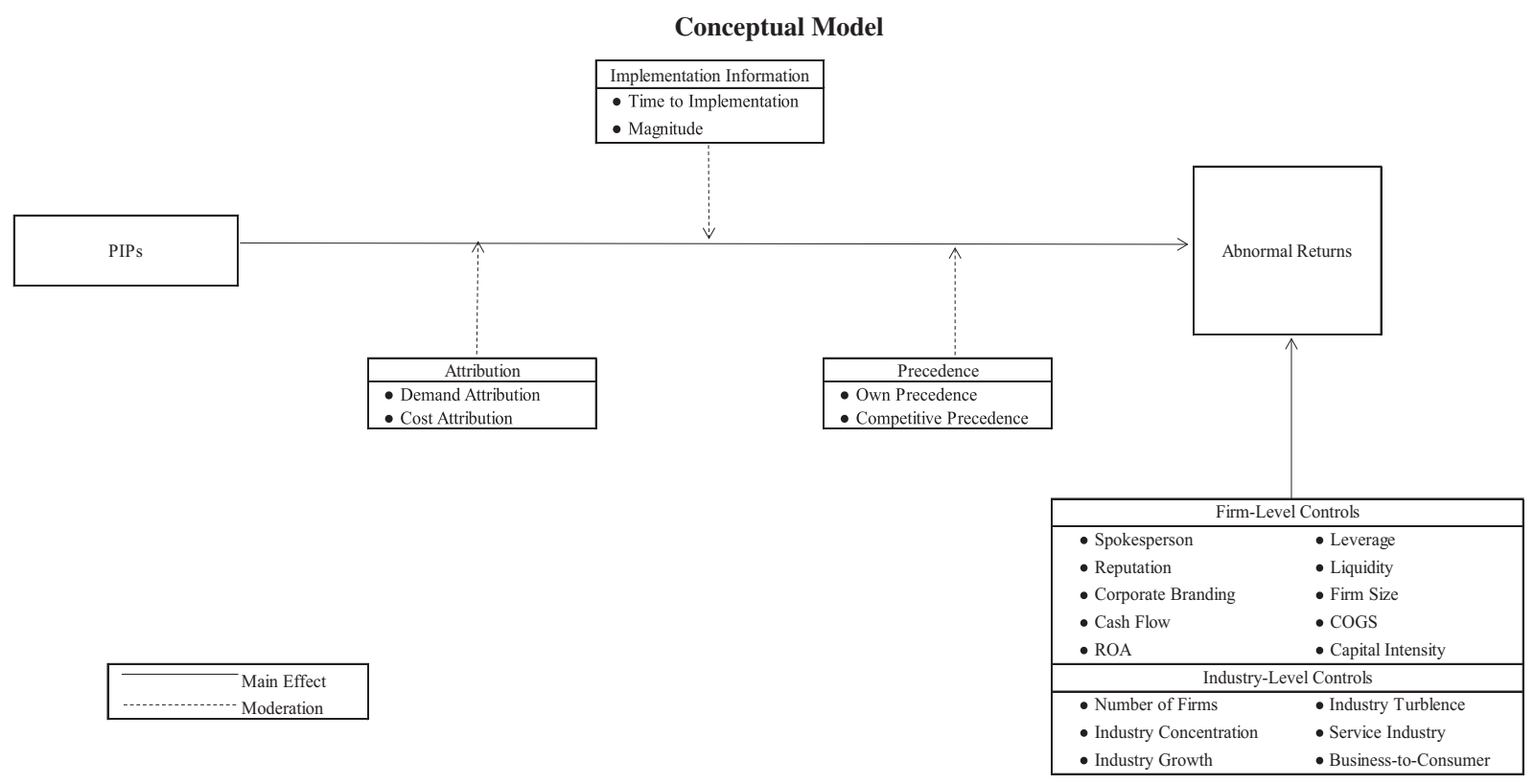

Fig. 1. Notes. PIP = Price-Increase Preannouncement; ROA = Return on Assets; COGS = Cost of Goods Sold.

A PIP takes place when a firm makes a public announcement of a future price increase. The fundamental concern for investors is the expected effect of a PIP on the future cash flows of the firm (Srinivasan \& Bharadwaj, 2004). If investors consider a PIP to result in an increase (decrease) in future cash flows, they are likely to adjust the stock price of the firm upwards (downwards), resulting in positive (negative) abnormal returns.

Drawing on prior literature on preannouncements, we propose (as shown in Fig. 1) that investors' evaluations of a PIP are likely to be a function of three observable pieces of information: (1) the information contained in the PIP that characterizes the planned price increase (Implementation Information), (2) the underlying rationale for the PIP (Attribution), and (3) the prior PIP behaviour of the firm and its competitors (Precedence).

While a PIP can serve as a "necessary means" for a firm to communicate its future price level to customers (Smith, 2011, p. 283), it can also signal to investors the potential future earnings of the firm (Marn et al., 2004). Moreover, a PIP can also be conceived as a competitive market signal (Heil \& Langvardt, 1994), where the firm makes a PIP with the purpose of influencing the behaviour of its competitors (Prabhu \& Stewart, 2001). When developing our expectations, we assess the impact of each of the proposed drivers on abnormal returns by considering three perspectives: a customer, an economic and a competitive perspective. In doing so, we draw upon the shareholder value framework of Srivastava, Shervani, and Fahey (1998), and consider how future cash flows could be affected in terms of their level, stability, and timing. ${ }^{3}$ Then, following prior research (e.g., Geyskens, Gielens, \& Dekimpe, 2002), we derive expectations on the likely net effect on shareholder value by combining the arguments across the three perspectives.

From a customer's point of view, a PIP's impact on shareholder value is likely to depend on the likelihood and severity of any customer backlash following a PIP. Customers might react negatively to the PIP by reducing (or even terminating) their relationships with the firm resulting in lower levels of future cash flows. Customers may even vent their negative emotions by spreading unfavourable word-of-mouth about the firm or brand leading to an adverse effect on the purchase decisions of both current and potential customers (Luo, 2007). This, in turn, is likely to lower the stability of expected future cash flows. Negative word-ofmouth can also have an adverse effect on the timing of expected future cash flows, as it can make it more difficult (and time consuming) to convince prospective new customers (Luo \& Homburg, 2007). Drawing on the consumer behaviour literature, we argue that customers' perceived price unfairness (e.g., Xia, Monroe, \& Cox, 2004), their perceptions of the quality of the firm's offerings (e.g., Rao, 2005), and their costs of switching away from the firm (e.g., Burnham, Frels, \& Mahajan, 2003) are likely to inform investors of the probability and size of a potential customer backlash following a PIP.

From an economic perspective, investors are likely to take into account the PIP's implications in terms of revenues and costs (Geyskens et al., 2002). While both revenues and costs have a direct impact on the levels of the expected future cash flows of the firm (Srinivasan, Pauwels, Silva-Risso, \& Hanssens, 2009), the time at which the firm experiences the changes in revenues and costs, i.e., sooner or later, will accelerate or delay the firm's receipt of these expected future cash flows (Srivastava et al., 1998).

\footnotetext{
3 Srivastava et al. (1998) also identify the residual value as a fourth dimension of shareholder value. However, given that investors evaluate the net impact of a PIP on all expected future cash flows, the residual value of the firm's business is automatically incorporated into the valuation as an outcome of the level, stability and timing of expected future cash flows (see Srivastava, Shervani, \& Fahey, 1999, p. 173). Thus, consistent with existing research (e.g., Luo \& Homburg, 2008), we do not explicitly consider the effect of a PIP on the residual value of the firm's business in our conceptualization.
} 
Finally, a PIP's impact on shareholder value is also likely to be a function of the degree to which a firm is vulnerable to competition. Following a PIP, competitors can try to attract the firm's customers by keeping their own prices unchanged, by cutting their prices, or by increasing their prices to a lesser extent (Thomadsen, 2012). The higher the expected loss of current and potential customers to competitors, the lower investors' expectations will be about the level and stability of future cash flows, while the expected speed of reaction will affect the timing of these cash flows.

It is important to note that our objective is to develop expectations about the impact of a PIP on shareholder value at the time when the PIP is made. Thus, we formulate arguments for the effect of a PIP on the three aforementioned dimensions of expected future cash flows to arrive at a testable expectation about the combined (or net) effect on shareholder value. Consistent with prior event studies (e.g., Geyskens et al., 2002), we do not empirically test the effects of the independent variables on each separate underlying dimension. Table 1 outlines the three perspectives, along with the net expected effects on the resulting abnormal returns.

\subsection{Implementation information}

In assessing the impact of a PIP, investors are likely to focus on two fundamental attributes of the preannounced price increase, the time to its implementation and its magnitude. This is because time to implementation provides concrete information about the time at which the expected changes in future cash flows will accrue to the firm. It also signals the firm's commitment to implement the preannounced price increase (cf. Sorescu, Shankar, \& Kushwaha, 2007), as well as the concreteness of its intentions. On the other hand, magnitude communicates the per-unit impact of the preannounced price increase, and thereby helps investors to form expectations about its likely cash-flow impact (Marn et al., 2004).

\subsubsection{Time to implementation}

The duration between the date of the PIP and the date at which it becomes effective is the PIP's time to implementation. Greater time to implementation implies that customers have more time to forward buy (and bring in the associated cash flows earlier. However, this situation also implies that customers incur lower cost of switching away from the firm as they have more time to search and are hence more likely to evaluate (and try) alternatives (Ratchford, 2009). Thus, the customer perspective is inconclusive on the net impact of time to implementation on expected future cash flows.

From both the economic and competitive perspective, time to implementation is likely to have a negative impact on the expected future cash flows. This is because if the preannounced price increase corresponds to a better (more profitable) price for the firm, then purchases made between the day of the PIP and its effective date will be less profitable for the firm. More importantly, when a firm preannounces a price increase far ahead in time, it becomes more vulnerable to competitors' actions as they have more time to fine tune their strategies to attract the firm's customers (Kohli, 1999).

Taken together, we argue that concerns from an economic and competitive perspective will outweigh the customer considerations, and result in investors having an overall negative evaluation of PIPs with greater (as compared to lower) time to implementation. Therefore, we expect greater time to implementation of the preannounced price increase to result in lower associated abnormal returns.

\subsubsection{Magnitude}

Magnitude refers to the level of the price increase that is preannounced. A PIP with higher magnitude might be viewed as a signal of the firms' confidence in the quality of its offerings (Rao, 2005). However, such PIPs have a greater likelihood of exceeding customers' price threshold and engage their price sensitivity (Pauwels, Srinivasan, \& Franses, 2007). Relatedly, customers also have a greater incentive to search for and evaluate competing offerings (Burnham et al., 2003). As such, the switching costs for customers are likely to become lower following PIPs with higher magnitude. Thus, from a customer perspective, such PIPs are likely to result in a negative impact on expected future cash flows.

From an economic perspective, PIPs of higher magnitude can have a positive effect on expected future cash flows. This is because such PIPs not only correspond to higher revenues per unit sold, they also provide customers with a greater incentive to

Table 1

Expected effect of key drivers on investors' evaluations of a PIP.

\begin{tabular}{|c|c|c|c|c|}
\hline & Customer & Economic & Competitive & Expected net effect on investors' evaluations of a PIP \\
\hline \multicolumn{5}{|l|}{ Implementation information } \\
\hline Time to implementation & $+1-$ & - & - & - \\
\hline Magnitude & - & + & $+1-$ & $?$ \\
\hline \multicolumn{5}{|l|}{ Attribution } \\
\hline Demand attribution & $+1-$ & + & + & + \\
\hline Cost attribution & + & - & - & - \\
\hline \multicolumn{5}{|l|}{ Precedence } \\
\hline Own precedence & - & - & - & - \\
\hline Competitive precedence & + & - & - & - \\
\hline
\end{tabular}

Notes. PIP = Price-Increase Preannouncement. Consistent with Geyskens et al. (2002), a "+" signifies that we expect the variable in question to have a favourable effect on the firm's expected future cash flows (and hence investors' evaluations of the PIP), a "- " signifies a negative effect, a "+/-" signifies that there are good arguments for both a positive and a negative effect, and a "?" signifies that we do not advance any a priori expectations on the net effect. 
move their purchases forward to take advantage of the current (lower) price (Bijmolt, van Heerde, \& Pieters, 2005). Price increases of higher magnitude also signal the presence of a "core loyal customer base with a strong need or desire" for the firm's offerings such that they will continue to purchase from the firm "even at very high prices" (Pauwels et al., 2007, p. 85). Such loyal customers, in turn, suggest that PIPs with higher magnitude are likely to result in a higher expected future cash flows from a competitive perspective. However, if competitors do not follow this increase, a firm's relative price position will deteriorate more, hence making it more vulnerable to competition. This is likely to have a negative impact on investors' expectations of its future cash flows. Thus, from a competitive perspective, the net impact of magnitude on expected future cash flows is unclear.

Given that the customer (negative), economic (positive), and competitive (positive or negative) perspectives provide good arguments for both a positive and a negative effect, we examine the impact of the magnitude of the preannounced price increase on the associated abnormal returns in an exploratory fashion.

\subsection{Attribution}

The reason(s) provided by a firm for raising the price charged to customers is referred to as the PIP's attribution. Since a price increase can only result in an overall increase in future cash flows if it is not offset by a proportionate decrease in the quantity sold, the cash-flow implications of a preannounced price increase due to rising demand are likely to be different from those of rising costs (Prabhu \& Stewart, 2001). Thus, investors are likely to evaluate a preannounced price increase differently depending on whether the firm attributes it to rising demand, i.e., a Demand Attribution, or to rising costs, i.e., a Cost Attribution.

\subsubsection{Demand attribution}

A firm provides a demand attribution in its PIP if it states that the reason for its preannounced price increase is an increase in the demand for its offerings. A preannounced price increase is likely to be perceived as unfair if it is attributed to rising demand (Kwak, Puzakova, \& Rocereto, 2015). This is because customers are likely to infer that the firm will enjoy additional profits while making them bear the burden of higher prices (Campbell, 1999). However, rising demand also suggests that there is greater adoption of the firm's offerings, thus signalling to customers that the firm is offering high-quality products and/or services that provide unique benefits (Hellofs \& Jacobson, 1999). Therefore, from a customer's perspective, it is unclear if a PIP citing demand attribution is likely to increase or reduce expected future cash flows. However, from an economic perspective, citing a demand attribution in a PIP is likely to have a positive impact on the expected future cash flows. This is because higher demand indicates that the per-unit impact of the preannounced price increase will apply to a high(er) number of units sold.

Given that rising demand also signals to investors the firm's ability to increase its customer base, investors are likely to be more confident about the firm's value proposition, and hence less likely to be concerned about competitors' ability to attract its customers (e.g., Prabhu \& Stewart, 2001). Importantly, customers of firms with rising demand are also likely to be more loyal as they tend to have more positive attitudes toward the firm's offerings (Koschate-Fischer, Cramer, \& Hoyer, 2014). As such, from a competitive perspective, PIPs with a demand attribution are likely to have a positive impact on expected future cash flows.

In summary, a joint consideration of the customer, economic, and competitive perspectives suggest that investors have more reasons to expect a PIP with a demand attribution to result in higher associated abnormal returns.

\subsubsection{Cost attribution}

A firm provides a cost attribution in a PIP if it states that the reason for the preannounced price increase is an increase in its cost of doing business. Customers are less likely to perceive a preannounced price increase as unfair if it is due to an increase in firm costs (Bolton, Warlop, \& Alba, 2003). This is because customers view such price increases as an attempt by the firm to maintain (rather than increase) its existing level of profit (Campbell, 1999). As such, from a customer perspective, a cost attribution in a PIP is likely to have a positive impact on the expected future cash flows.

From an economic perspective, however, a cost attribution in a PIP indicates that rising costs are likely to (partially or fully) offset any benefits of higher revenues due to the price increase. Rising costs also indicate that the firm is likely to be more resource constrained, and thus more vulnerable to competition (Lee \& Grewal, 2004). This is because a firm facing rising costs is likely to be handicapped by the resulting budget constraints when facing competitors. Thus, from a competitive perspective, PIPs citing cost attribution are likely to result in a negative impact on expected future cash flows.

In summary, even though it is less probable for customers to perceive a PIP with a cost attribution to be unfair, economic and competitive considerations suggest that a PIP with a cost attribution is likely to lower investors' expectations about the future cash flows. Hence, we expect PIPs that provide a cost attribution to result in lower associated abnormal returns.

\subsection{Precedence}

Precedence refers to the prior preannouncement behaviours of the firm and its competitors. Recent research finds that investors rely on the historical preannouncement behaviour of the firm and its competitors as an important information source to form an understanding of the firm's unobservable pricing strategies (Warren \& Sorescu, 2017). Accordingly, we examine both the firm's own precedence of PIPs, and that of its competitors. 


\subsubsection{Own precedence}

A firm's own precedence of prior PIPs refers to the number of PIPs made by the firm before the current PIP. Customers are likely to perceive PIPs with higher own precedence as unfair. This is because customers' perceptions of price unfairness are based on their comparisons between the price they currently pay and a range of past prices that they have paid (Bolton et al., 2003; Kalyanaram \& Winer, 1995). The more frequent the PIPs by a firm, the more salient the price attribute becomes (Nijs, Dekimpe, Steenkamps, \& Hanssens, 2001), and the more likely customers will notice that the preannounced new price exceeds previously-paid prices (Rajendran \& Tellis, 1994). The increased salience is also likely to influence the future price expectations for the firm's current and future customers, resulting in a higher price sensitivity and lower willingness to pay (DelVecchio, Shanker Krishnan, \& Smith, 2007). Thus, from a customer's perspective, such PIPs are likely to result in a negative impact on expected future cash flows.

From an economic perspective, a firm incurs a menu cost, i.e., the cost of revising prices (Anderson, Jaimovich, \& Simester, 2015), when it makes a PIP. PIPs with higher own precedence are likely to result in higher menu costs and therefore lower per-unit profits for the firm. As such, from an economic perspective, such PIPs are likely to have a negative impact on the expected future cash flows for the firm.

PIPs with higher own precedence also provide competitors with more opportunities to learn about the firm, as each additional PIP offers some information about the firm's underlying pricing strategy (Eliashberg \& Robertson, 1988). This, in turn, is likely to increase competitors' likelihood of identifying the best response to a firm's PIP (Montgomery, Moore, \& Urbany, 2005), hence increasing the firm's vulnerability to competition. As such, from a competitive perspective, making frequent PIPs is likely to reduce investors' expectations on the future cash flows for the firm.

In summary, concerns from the customer, economic and competitive perspectives suggest that higher own precedence of prior PIPs is likely to lower investors' expectations about the future cash flows for the firm leading to lower associated abnormal returns.

\subsubsection{Competitive precedence}

The number of PIPs made by a firm's competitors before its current PIP reflects the competitive precedence of a PIP. Customers evaluate the fairness of a firm's preannounced price increase by comparing it with competitors' prices and pricing practices (Bolton et al., 2003). If a firm makes a PIP after a number of its competitors have done so, it is less likely for customers to perceive the preannounced price increase as unfair because the new price is comparable to the prices offered in the market (Xia et al., 2004).

From an economic perspective, however, higher competitive precedence is likely to result in a negative effect on the firm's expected future cash flows. When a firm makes a PIP with higher competitive precedence, investors may perceive its delay in raising prices as "leaving money on the table" (Prushan, 1997). By waiting for its competitors to make PIPs, the firm foregoes an opportunity to accrue higher cash flows (Marn et al., 2004).

Furthermore, higher competitive precedence also signals to investors that the firm is not confident about its ability to increase prices without losing customers (Keil, Reibstein, \& Wittink, 2001). That is, the firm appears to lack a loyal customer base since it can only make a PIP after the industry has become accustomed to the notion of price increases. In this way, the lack of confidence is likely to signal the firm's vulnerability to competitors' actions (Prabhu \& Stewart, 2001). As such, from a competitive perspective, competitive precedence is likely to have a negative impact on the expected future cash flows for the firm.

Taken together, although the customer perspective proposes a positive effect of competitive precedence, economic and competitive considerations suggest that competitive precedence is likely to have a negative effect on shareholder value. Thus, we expect higher competitive precedence of prior PIPs to result in lower associated abnormal returns.

\section{Method}

To identify PIPs, we use the electronic search engine FACTIVA that allows us to search all major US-based newspapers and trade publications to identify PIPs made between 2010 and 2014 by publicly-listed US firms. ${ }^{4}$ We do not consider observations from utility, finance and insurance industries, as prices in these industries are typically heavily regulated (Morgan \& Rego, 2009). This resulted in 749 observations from 128 firms.

To avoid potential confounds, we do not consider announcements that are in close proximity ( \pm 2 days) to other major events (for details, see Web Appendix A). In addition, we eliminate PIPs if we cannot determine their release date, and if their accounting and stock-returns data are not available in COMPUSTAT and the University of Chicago Centre for Research in Security Prices (CRSP). In case of multiple release dates, we use the earliest date as the release date of the PIP. These criteria produced a preliminary sample of 621 PIPs from 113 firms. Since we focus on the time to implementation and magnitude of a PIP, we use the PIPs that provided information about these variables. Our final sample consists of 274 PIPs between 2010 and 2014 from 80 firms (for details, see Web Appendix B). ${ }^{5}$

\footnotetext{
${ }^{4}$ We only consider non-commodity PIPs because commodities such as oil and natural gas are heavily traded in commodity exchanges. We identify a product as a commodity if it is listed on the Chicago Mercantile Exchange (CME) (Bruno, Che, \& Dutta, 2012). Using FACTIVA's "Intelligent Indexing”, we restrict our search to only US publications by selecting a source grouping (i.e., Publications - By Region) and a regional indexing term (i.e., United States) in FACTIVA. The keywords used in the search are combinations of "price" and "increase", "jump", hike", "raise", "rise", "increment”, etc. In addition, we do not consider PIPs from foreign companies listed in the US, as prior research in finance suggests that investors may possess different preferences for domestic versus foreign equities (Coval \& Moskowitz, 1999).

${ }^{5}$ For all subsequent mentions of PIPs, we are referring to PIPs that provide information on time to implementation and magnitude. However, we will also consider the larger sample of 621 PIPs (i.e., thereby also considering the PIPs that do not disclose information on time to implementation and/or magnitude of a PIP) in our sensitivity analyses. The reduction in the final sample size (i.e., 274) from the total number of public preannouncements of price increases (i.e., 749) is consistent with prior event studies in marketing. Hsu and Lawrence (2016), for example, start with 2124 announcements of public recalls and use a final sample of 185 announcements.
} 
We estimate abnormal returns following a PIP as a function of the information available to investors on the day when the PIP is made. As such, all variables are measured as of the day of the PIP. For the variables that reflect periodically released firm financial information, we use the annual report released in the closest financial year preceding the PIP. Following prior work (e.g., Rust \& Huang, 2012), we identify the firm's industry using its six-digit North American Industry Classification System (NAICS) code.

\subsection{Dependent variable}

We adopt the event-study method and estimate the abnormal returns following a PIP. According to the efficient-market hypothesis, stock prices reflect the impact of all publicly-available information about a firm on its future cash flows (MacKinlay, 1997). When a firm makes a PIP, investors update their expectations of the firm's future cash flows and adjust the price of the firm's stock accordingly. If investors expect the PIP to result in an increase (decrease) in future cash flows, the stock price will increase (decrease). The benefit of an event-study is that it allows an inference of cause (PIPs) and effect (abnormal returns) in a quasi-experimental setting (Srinivasan \& Hanssens, 2009). The approach is widely used to assess investors' evaluations of marketing actions, such as CMO successions (e.g., Wang, Saboo, \& Grewal, 2015) and product recalls (e.g., Hsu \& Lawrence, 2016).

We assess the effect of a PIP (the "event") on the stock price of a firm by estimating the change in its stock price after accounting for firm and market factors (i.e., the risk-adjusted abnormal stock return of the firm) during a specified time window around the event date. The risk-adjusted abnormal stock return of the focal firm is measured as the difference between the firm's expected and actual stock returns (Eq. (1)):

$$
A R_{i j t}=R_{i j t}-\left(a_{i j}+\beta_{i j} R_{m t}+s_{i j} S M B_{t}+h_{i j} H M L_{t}+u_{i j} U M D D_{t}\right),
$$

where $\mathrm{AR}_{\mathrm{ijt}}$ is the abnormal return of firm $i$ of industry $j$ on day $t$ (i.e., the day of the PIP), $\mathrm{R}_{\mathrm{ijt}}$ is the firms' actual stock return, $\mathrm{R}_{\mathrm{mt}}$ the return on a value-weighted portfolio of the total stock market, $\mathrm{SMB}_{t}$ the Fama and French (1993) size portfolio return, $\mathrm{HML}_{t}$ the Fama and French (1993) book-to-market-ratio portfolio return, and $\mathrm{UMD}_{\mathrm{t}}$ the Carhart (1997) momentum portfolio return, all on day $t . a_{i j}, \beta_{i j}, s_{i j}, h_{i j}$ and $u_{i j}$ are parameters estimated over a 250 day period ending 30 days before the event date. We use the CRSP database to obtain daily stock returns from a value-weighted market index comprising all stocks on NASDAQ and NYSE.

\subsection{Independent variables}

\subsubsection{Time to implementation}

Time to Implementation is measured as the number of days between the date of the PIP and the date the preannounced price increase becomes effective (for examples, see Web Appendix C, Table C1). PIPs in our sample were made as early as 131 days (W.R. Grace and Company in August 2010) or as late as one day (Carpenter Technology in April 2011) before implementation.

\subsubsection{Magnitude}

We measure the magnitude of the preannounced price increase as the percentage change in the price of the firm's product and/or service before and after the PIP (for examples, see Web Appendix C, Table C1). In our sample, firms make PIPs with magnitudes ranging from as low as 1\% (Starbucks in June 2013) to as high as 63\% (DISH Network Corporation in December 2013).

\subsubsection{Demand and cost attribution}

We measure attribution through the reasons given in the PIP to justify the increase in price. To identify the reasons for the preannounced price increase, the PIPs were first content-analyzed to identify phrases and combinations of words that are commonly used to justify the need for a price increase.

To identify PIPs with a demand attribution, the keywords include combinations of words such as, "demand", "profit(s)", "revenue(s)", "growth", and "increase", "change", "strong”. In addition, we used specific phrases such as "facilitate organic growth", "rebalance the marketplace", "support continued growth and investment". In coding PIPs with a cost attribution, the set of keywords includes combinations of words such as "cost" or "costs" and "increase", "input", "operating", "transportation", "logistic", "raw materials" (for examples, see Web Appendix C, Table C2).

Second, two judges independently examined the PIPs to identify the attributions, and then compared notes to arrive at an agreement. We find that 76 out of 274 (i.e., 28\%) of the PIPs in our sample cite demand attributions while 138 out of 274 (i.e., 50\%) of the PIPs in our sample cite cost attributions.

\subsubsection{Own and competitive precedence}

Following Warren and Sorescu (2017), we measure own (competitive) precedence as the natural logarithm of the number of PIPs by the firm (competitors) in the year preceding the focal PIP, where we define competitors as firms within the same six-digit NAICS code as the focal firm. ${ }^{6}$ We compute these variables using PIPs from the most recent year because prior research suggests

\footnotetext{
${ }^{6}$ The computation of Own Precedence and Competitive Precedence also includes price-increase announcements that 1) were post-announcements, 2) were made on the day the announced price increase becomes effective, 3) do not provide sufficient information about the magnitude of the change in prices and the effective date of the announced price increase, and 4 ) were in close proximity (i.e., \pm 2 days) to other events such as earnings announcements. In addition, the computation of Competitive Precedence also includes PIPs that were from foreign companies listed in the US.
} 
that investors weight recent information more heavily (Sorescu et al., 2007). Using a one-year time window not only allows sufficient variation to examine the PIP history of the firm and its competitors, it also more accurately captures the investors' state of mind when they are evaluating the firm's PIP (e.g., Warren \& Sorescu, 2017). We find that some firms made as many as 30 PIPs in the preceding year, while others did not make any PIPs during that period. For competitive precedence, we find that while some PIPs are preceded by 48 competitive PIPs, others are the first PIP to be made in the industry within a year. Finally, to account for potential diminishing returns to scale effects of our continuous drivers, we take the natural logarithm of Time to Implementation, Magnitude, and Own and Competitive Precedence. ${ }^{7}$

\subsection{Control variables}

We control for several factors that are likely to have an impact on abnormal returns. First, we control for firm-related nonfinancial variables that may result in systematic differences in investors' evaluations of a PIP. Research in consumer behaviour and psychology suggests that the source of price information "can influence evaluations and perceptions of outcomes" (Campbell, 2007, p. 262). Since PIP made by the top management team or the chief executive officer can be perceived differently from PIPs made by other members of the firm (Sorescu et al., 2007), we account for the Spokesperson of the PIP as a control variable in our model.

Prior research suggests that the firm's overall reputation is likely to influence investors' evaluations of its announcements, where investors might discount the reliability of PIPs from low-reputation firms (Sorescu et al., 2007). Consistent with existing research, we use a firm's presence on Fortune magazine's Most Admired Company list to account for the firm's overall Reputation (e.g., Mishra \& Modi, 2016).

In addition, due to the potential spill-over effects of a PIP from one brand to other brands in the firm's portfolio (e.g., Larkin, 2013), the impact of a PIP from a mono-brand firm may differ significantly from that of a multi-brand firm. Hence, we control for whether a firm adopts a Corporate Branding strategy. Following Rao, Agarwal, and Dahlhoff (2004), we determine the branding strategy of firms for a particular financial year by examining their 10-K statements obtained from the SEC (U.S. Securities and Exchange Commission) and their corporate webpages to uncover information regarding the product and/or service brands marketed by these firms. A firm is coded as having a corporate branding strategy if it predominantly uses its corporate name on its products and/or services.

Following prior research, we also control for several firm financial characteristics. Specifically, a firm's profitability encompasses financial information that influences investors' evaluations of a firm's stock (Luo, 2007). Following Gruca and Rego (2005), we use both a firms' net operating Cash Flows and earnings, measured by its Return on Assets, to account for its profitability. To take into account the capital structure of the firm, we include Leverage and Liquidity, as investors are likely to prefer firms with lower leverage (Malshe \& Agarwal, 2015) and higher liquidity (Luo, Homburg, \& Wieseke, 2010). Since investors tend to have a preference for the stocks of larger firms (Rubera \& Kirca, 2012), we also control for Firm Size. Prior research suggests that the expected profits following a PIP are likely to be different for firms facing different operating costs (Rust, Moorman, \& Dickson, 2002). As such, we include a firm's cost of goods sold, i.e., its COGS, as a control variable. Finally, we also control for a firm's Capital Intensity as capital- (vs. labor-) intensive firms are likely to adopt different operating strategies (McAlister, Srinivasan, Jindal, \& Cannella, 2016).

We include several industry covariates to account for the differences in investor responses to PIPs across industries. First, we control for the competitive structure of an industry by including both the total Number of Firms in the industry and the Industry Concentration (to account for the distribution of the market shares of firms). Following Fang, Palmatier, and Steenkamp (2008), we also include Industry Growth and Turbulence as they are likely to have an impact on firm value. We also account for whether or not a PIP is made by a firm operating in a Service Industry, as investors may evaluate the stock of a product- (vs. service-) focused firm differently (Morgan \& Rego, 2009). Finally, we control for whether a firm is operating in a Business-to-Consumer industry as the price dynamics in such industries are typically different from industries that sell mainly to businesses.

Table 2 outlines the control variables, their measures, data sources and examples of studies that support the use of these measures.

\subsection{Model specification}

We test our expectations using Eq. (2), where the abnormal returns $\left(\mathrm{AR}_{\mathrm{ijt}}\right)$ are a function of the information that investors have at the time of the preannouncement:

$$
\mathrm{AR}_{\mathrm{ijt}}=\gamma_{0}+\gamma_{1} \mathrm{TIME}_{\mathrm{ijt}}+\gamma_{2} \mathrm{MAG}_{\mathrm{ijt}}+\gamma_{3} \mathrm{DB}_{\mathrm{ijt}}+\gamma_{4} \mathrm{CB}_{\mathrm{ijt}}+\gamma_{5} \mathrm{OWN}_{\mathrm{ijt}}+\gamma_{6} \mathrm{COMP}_{\mathrm{ijt}}+\gamma_{7} \mathrm{CNTRLS}_{\mathrm{ijt}}+\epsilon_{\mathrm{ijt}}
$$

where TIME $E_{\mathrm{ijt}}$ and $\mathrm{MAG}_{\mathrm{ijt}}$ are the (log-transformed) time to implementation and magnitude of the preannounced increase featured in the PIP from firm $i$ of industry $j$ on day $t, \mathrm{DB}_{\mathrm{ijt}}$ and $\mathrm{CB}_{\mathrm{ijt}}$ are dummy variables indicating whether or not there are demand and cost attributions, $\mathrm{OWN}_{\mathrm{ijt}}$ and $\mathrm{COMP}_{\mathrm{ijt}}$ represent the (log-transformed) own and competitive precedence, and the coefficient vector

\footnotetext{
7 Since Time to Implementation, Magnitude, Own Precedence and Competitive Precedence can have very small values, we use the transformation of, for example, In (Time to Implementation +1 ) to compute the log-transformation of Time to Implementation. A similar transformation was performed for Magnitude, Own Precedence and Competitive Precedence.
} 
Table 2

Control variables, measures, and data sources.

\begin{tabular}{|c|c|c|c|}
\hline Variable & Measure & Source & Prior Support \\
\hline Spokesperson & $\begin{array}{l}\text { Equals } 1 \text { if the PIP is made by members of the top } \\
\text { management team or the chief executive officer; } 0 \\
\text { otherwise. }\end{array}$ & FACTIVA & Sorescu et al. (2007) \\
\hline Reputation & $\begin{array}{l}\text { Equals } 1 \text { for firms that were on the list of Fortune } \\
\text { magazine's Most Admired Company; } 0 \text { otherwise. }\end{array}$ & $\begin{array}{l}\text { Fortune Magazine Most } \\
\text { Admired Company }\end{array}$ & Mishra and Modi (2016) \\
\hline Corporate branding & $\begin{array}{l}\text { Equals } 1 \text { if the firm predominantly uses its } \\
\text { corporate name on its products and/or services; } 0 \\
\text { otherwise. }\end{array}$ & SEC; Company Webpage & Rao et al. (2004) \\
\hline Cash flows & $\begin{array}{l}\text { Net cash flows from operating activities of the firm } \\
\text { (DT: OANCF) scaled by its total assets (DT: AT). }\end{array}$ & COMPUSTAT & $\begin{array}{l}\text { Vomberg, Homburg, and } \\
\text { Bornemann (2015) }\end{array}$ \\
\hline ROA & $\begin{array}{l}\text { The firm's operating income (DT: OIBDP) scaled by } \\
\text { its total assets (DT: AT). }\end{array}$ & COMPUSTAT & Fang et al. (2008) \\
\hline Leverage & $\begin{array}{l}\text { Ratio of the firm's total long-term debt (DT: DLTT) } \\
\text { to its market capitalization, where market } \\
\text { capitalization is the product of the stock price (DT: } \\
\text { PRCC) and the total number of outstanding shares } \\
\text { (DT: CSHO). }\end{array}$ & COMPUSTAT & $\begin{array}{l}\text { Grewal, Chandrashekaran, } \\
\text { and Citrin (2010) }\end{array}$ \\
\hline Liquidity & $\begin{array}{l}\text { Ratio of the current assets (DT: ACT) to the current } \\
\text { liabilities (DT: LCT). }\end{array}$ & COMPUSTAT & Luo et al. (2010) \\
\hline Firm size & $\begin{array}{l}\text { The natural logarithm of a firm's total revenues } \\
\text { (DT: REVT). }\end{array}$ & COMPUSTAT & Robinson et al. (2015) \\
\hline COGS & $\begin{array}{l}\text { Ratio of the firm's cost of goods sold expenses (DT: } \\
\text { COGS) to the firm's total revenues (DT: REVT). }\end{array}$ & COMPUSTAT & $\begin{array}{l}\text { Mittal, Anderson, Sayrak, and } \\
\text { Tadikamalla (2005) }\end{array}$ \\
\hline Capital intensity & $\begin{array}{l}\text { Ratio of the firm's net plant, property, and } \\
\text { equipment (DT: PPENT) to its total assets (DT: AT). }\end{array}$ & COMPUSTAT & McAlister et al. (2016) \\
\hline Number of firms & $\begin{array}{l}\text { The natural logarithm of the total number of firms } \\
\text { in an industry at the end of each fiscal year }\end{array}$ & COMPUSTAT & Nachum and Zaheer (2005) \\
\hline Industry concentration & $\begin{array}{l}\text { Hirschman-Herfindahl index (HHI) within the } \\
\text { firm's six-digit NAICS (DT: REVT). }\end{array}$ & COMPUSTAT & $\begin{array}{l}\text { Fang, Palmatier, and Grewal } \\
\text { (2011) }\end{array}$ \\
\hline Industry growth & $\begin{array}{l}\text { Average of the three year-over-year revenue } \\
\text { growth in an industry, where the year-over-year } \\
\text { revenue growth is the percentage change in the } \\
\text { sum of the revenues of the firms within the same } \\
\text { six-digit NAICS code at the end of the current fiscal } \\
\text { year from the end of the preceding fiscal year (DT: } \\
\text { REVT). }\end{array}$ & COMPUSTAT & $\begin{array}{l}\text { Bahadir, Bharadwaj, and } \\
\text { Srivastava (2008) }\end{array}$ \\
\hline Industry turbulence & $\begin{array}{l}\text { Standard deviation of the sum of the revenues of } \\
\text { the firms in the same six-digit NAICS code across } \\
\text { the prior four years divided by the mean value of } \\
\text { the sum of the total revenues of the firms within } \\
\text { the same six-digit NAICS code for those four years } \\
\text { (DT: REVT). }\end{array}$ & COMPUSTAT & Fang et al. (2008) \\
\hline Service industry & $\begin{array}{l}\text { Firms with a six-digit NAICS code beginning with } \\
42-92 \text { are coded as firms in the service industry. }\end{array}$ & COMPUSTAT & Rust and Huang (2012) \\
\hline Business-to-Consumer & $\begin{array}{l}\text { Equals to } 1 \text { if the firm's six-digit NAICS code sells } \\
\text { mostly to end-consumers; } 0 \text { otherwise. }\end{array}$ & COMPUSTAT & $\begin{array}{l}\text { Kalaignanam and Cem Bahadir } \\
\text { (2013) }\end{array}$ \\
\hline \multicolumn{4}{|c|}{ Exclusion restrictions for selection equation } \\
\hline Percentage of institutional holdings & $\begin{array}{l}\text { Percentage of shares outstanding with all reporting } \\
\text { institutions for each firm (DT: INSTOWN_PERC). }\end{array}$ & $\begin{array}{l}\text { Thomson Financial Institutional } \\
\text { Holdings (13F) }\end{array}$ & Nagel (2005) \\
\hline Economic growth & $\begin{array}{l}\text { Percentage change in gross domestic product } \\
\text { (based on current dollars) reported in the } \\
\text { preceding fiscal quarter. }\end{array}$ & $\begin{array}{l}\text { BEA of the US Department of } \\
\text { Commerce }\end{array}$ & Lee and Grewal (2004) \\
\hline Year dummy variables & $\begin{array}{l}\text { Year dummy variables for 2010-2014 (reference } \\
\text { year: 2010) }\end{array}$ & FACTIVA & $\begin{array}{l}\text { Homburg, Vollmayr, and Hahn } \\
\text { (2014) }\end{array}$ \\
\hline
\end{tabular}

Notes. PIP = Price-Increase Preannouncement; DT = Data Item; SEC = U.S. Securities and Exchange Commission; BEA = Bureau of Economic Analysis; $\mathrm{ROA}=$ Return on Assets; COGS = Cost of Goods Sold; NAICS = North American Industry Classification System. All variables in this table are measured using the financial information from the annual report released in the closest financial year preceding the PIP. In line with prior research, we replace the missing values of the following variables with zero: long-term debt (e.g., Robinson et al., 2015) and percentage of institutional holdings (e.g., Nagel, 2005).

$\gamma_{7}$ denotes the effect of the set of control variables CNTRLS $S_{i j t}$ (i.e., Spokesperson, Reputation, Corporate Branding, Cash Flows, Return on Assets, Leverage, Liquidity, Firm Size, COGS, Capital Intensity, Number of Firms, Industry Concentration, Industry Growth, Industry Turbulence, Service Industry and Business-to-Consumer). To account for the potential correlation among PIPs from firms within the same industry, we allow the error terms of observations of firms within an industry to be correlated with each other (Robinson, Tuli, \& Kohli, 2015).

Using OLS to estimate the proposed model (i.e., Eq. (2)) can lead to biased estimates as there are two potential sources of endogeneity (Gielens, Geyskens, Deleersnyder, \& Nohe, 2017). First, because some of the factors that influence the abnormal 
returns might also affect the firm's probability of making a PIP, the model specified in Eq. (2) is likely to yield biased estimates due to a selection bias (Hamilton \& Nickerson, 2003). For example, whereas investors are likely to view price increases less favorably for firms with lower profitability, such firms are also more likely to make a PIP. Thus, we specify a selection model to estimate a firm's likelihood of making a PIP to address this concern.

Second, our expected main effects can also potentially suffer from omitted variable bias, as these variables could be correlated with unobservable factors that affect the abnormal returns following a PIP. To address this concern, we follow Gielens et al. (2017) and draw upon Park and Gupta's (2012) Gaussian copulas approach to account for the potential endogeneity of the continous PIP characteristics (Time to Implementation, Magnitude, Own and Competitive Precedence). In addition, we use the Hausman-Wu test to assess the potential endogeneity of the dummy variables that reflect, respectively, Demand and Cost Attribution (e.g., Clement, Wu, \& Fischer, 2014).

\subsubsection{Addressing selection bias}

We jointly estimate Eq. (2), i.e., the outcome model, and the selection model (Eq. (3)) using Maximum Likelihood (ML), as opposed to the Heckman (1979) two-step estimation as it produces more efficient estimates (Breen, 1996):

$$
\begin{aligned}
& \mathrm{LIC}_{\mathrm{ijT}}=\delta_{0}+\delta_{1} \mathrm{REP}_{\mathrm{ijT}}+\delta_{2} \mathrm{CORP}_{\mathrm{ijT}}+\delta_{3} \mathrm{CFTA}_{\mathrm{ijT}}+\delta_{4} \mathrm{ROA}_{\mathrm{ijT}}+\delta_{5} \mathrm{LEV}_{\mathrm{ijT}}+\delta_{6} \mathrm{LIQ}_{\mathrm{ijT}} \\
& +\delta_{7} \mathrm{SIZE}_{\mathrm{ijT}}+\delta_{8} \mathrm{COGS}_{\mathrm{ijT}}+\delta_{9} \mathrm{CI}_{\mathrm{ijT}}+\delta_{10} \mathrm{NF}_{\mathrm{jT}}+\delta_{11} \mathrm{IC}_{\mathrm{jT}}+\delta_{12} \mathrm{IG}_{\mathrm{jT}}+\delta_{13} \mathrm{IT}_{\mathrm{jT}} \\
& +\delta_{14} \mathrm{SVC}_{\mathrm{j}}+\delta_{15} \mathrm{~B}_{2} \mathrm{C}_{\mathrm{j}}+\left[\delta_{16} \mathrm{INST}_{\mathrm{ijT}}+\delta_{17} \mathrm{EG}_{\mathrm{ijT}}+\sum_{\mathrm{k}=18}^{21} \delta_{\mathrm{k}} \mathrm{YEAR}_{\mathrm{T}}\right]+\mu_{\mathrm{ijT}}
\end{aligned}
$$

where LIC $_{\mathrm{ijT}}$ is 1 if firm $i$ in industry $j$ made a PIP in year $T$, else $0, \epsilon_{\mathrm{ijt}}$ is the error term for the outcome model $\sim N(0,1), \mu_{\mathrm{ijT}}$ is the error term for the selection model $\sim N(0,1)$, and $\rho$ denotes the correlation between $\epsilon_{\mathrm{ijt}}$ and $\mu_{\mathrm{ij} T}$.

The selection model includes several of the firm and industry control variables that are also included in the outcome model as these variables arguably affect not just the abnormal returns following a PIP, but are likely to also influence whether or not a firm makes a PIP. ${ }^{8}$ Specifically, we include Reputation $\left(\mathrm{REP}_{\mathrm{ijT}}\right)$ and Corporate Branding $\left(\mathrm{CORP}_{\mathrm{ijT}}\right)$ because the firm's overall reputation and/or branding strategy is likely to influence customers' price sensitivity toward its products and services (Bharadwaj, Tuli, \& Bonfrer, 2011), and hence can affect its likelihood to make a PIP.

Firms with lower Cash Flows $\left(\mathrm{CFTA}_{\mathrm{ijT}}\right)$ and Return on Assets $\left(\mathrm{ROA}_{\mathrm{ijT}}\right)$ but higher COGS $\left(\mathrm{COGS}_{\mathrm{ijT}}\right)$ and Capital Intensity $\left(\mathrm{Cl}_{\mathrm{ijT}}\right)$ are more likely to preannounce a price increase. This is because such firms generally have lower profits, and hence need the additional revenues expected from the PIP more than firms that already have higher earnings or lower costs (Homburg et al., 2005). Thus, we include these variables in the selection model. We also include Leverage ( $\operatorname{LEV}_{\mathrm{ijT}}$ ) and Liquidity (LIQ $\left.\mathrm{ijT}_{\mathrm{jT}}\right)$, as a firm with higher leverage and lower liquidity is more likely to preannounce a price increase to realize an increase in cash flows (Robinson et al., 2015). Finally, we also include Firm Size (SIZE $\mathrm{E}_{\mathrm{ijT}}$ ), as larger firms are more likely to make a PIP as they have more power to exert control and influence consumption patterns within the industry (Rubera \& Kirca, 2012).

The selection model also accounts for factors that reflect a firm's operating environment. Firms in monopolistic markets and/or more concentrated industries are more likely to make a PIP as lower competition results in higher prices (Ramaswamy, Gatignon, \& Reibstein, 1994). Thus, we include both Number of Firms $\left(\mathrm{NF}_{\mathrm{jT}}\right)$ and Industry Concentration (IC $\left.\mathrm{j}_{\mathrm{jT}}\right)$ in the selection model. Similarly, firms in industries with greater Industry Growth ( $\left.\mathrm{IG}_{\mathrm{jT}}\right)$ and Industry Turbulence ( $\left.\mathrm{IT}_{\mathrm{jT}}\right)$ are more likely to preannounce a price increase, because customers are less sensitive to prices in growing markets (Ramaswamy, Desarbo, Reibstein, \& Robinson, 1993), and are less likely to switch to unfamiliar brands in turbulent markets (Erdem \& Keane, 1996). Finally, given that our sample also includes PIPs from service-focused firms and/or firms that sell mainly to end-consumers, we also include Service Industry ( SVC $_{\mathrm{j}}$ ) and Business-to-Consumer $\left(\mathrm{B}_{2} \mathrm{C}_{\mathrm{j}}\right)$ in the selection model to control for potential systematic differences in firms' likelihood to make a PIP in these industries.

The selection model includes some additional variables - exclusion restrictions - that are not incorporated in the outcome model (i.e., the variables in the square brackets in Eq. (3)). A firm with a higher percentage of institutional holdings is under greater scrutiny to reduce information asymmetry through the disclosure of information that may affect its future cash flows (Bushee \& Noe, 2000). Since a price increase is likely to affect the future cash flows of a firm, we expect that firms with a higher percentage of institutional holdings are more likely to preannounce a price increase. That said, according to the efficient-market hypothesis, there is no reason to expect investors' evaluations of a PIP to be influenced by the level of institutional holdings of a firm's outstanding shares (Fama, 1991). As such, we include Percentage of Institutional Holdings (INST $\mathrm{ijT}_{\mathrm{T}}$ ) as an exclusion restriction.

Firms are less likely to make PIPs during periods of low economic growth as customers tend to be more price conscious in their purchase decisions and likely to slow down their spending (Deleersnyder, Dekimpe, Sarvary, \& Parker, 2004). As such, we also include Economic Growth $\left(\mathrm{EG}_{\mathrm{ijT}}\right.$ ) as an exclusion restriction. Finally, to account for the argument that unobserved time-related events may have influenced the firms' likelihood of making a PIP, we include Year Dummy variables (YEAR $\mathrm{T}_{\mathrm{T}}$ ) that correspond to the year in which the PIP was made. However, economic growth and the year dummy variables do not influence the abnormal returns. This is because the calculation of abnormal returns includes the return on a value-weighted portfolio of the total stock

\footnotetext{
${ }^{8}$ Some firm and industry factors included in the outcome model cannot be conceptualized/measured in the absence of a PIP (i.e., Time to Implementation, Magnitude, Demand Attribution, Cost Attribution, Own Precedence, Competitive Precedence and Spokesperson). Therefore, these variables are not included in the selection model.
} 
Table 3

Abnormal returns, $\mathrm{N}=274$.

\begin{tabular}{|c|c|c|c|c|c|c|c|c|c|c|c|}
\hline \multirow[t]{2}{*}{$\begin{array}{l}\text { Day } \\
\\
\\
-5\end{array}$} & \multirow{2}{*}{$\begin{array}{r}\text { Average AR (in \%) } \\
0.01\end{array}$} & \multicolumn{2}{|c|}{$\begin{array}{l}\text { Number of } \\
\text { PIPs with } \\
\text { positive } \\
\text { (Negative) } \\
\text { AR }\end{array}$} & \multicolumn{2}{|c|}{$\begin{array}{l}\% \text { of PIPs } \\
\text { with positive } \\
\text { (Negative) } \\
\text { AR }\end{array}$} & \multirow{2}{*}{$\begin{array}{r}\text { CSectErr (t) } \\
0.06\end{array}$} & \multirow[t]{2}{*}{$\begin{array}{r}\boldsymbol{p} \text {-value } \\
\\
0.48\end{array}$} & \multirow{2}{*}{$\begin{array}{r}\text { Rank Test (Z) } \\
-0.01\end{array}$} & \multirow{2}{*}{$\begin{array}{r}\boldsymbol{p} \text {-value } \\
\\
0.50\end{array}$} & \multirow{2}{*}{$\begin{array}{r}\text { Jackknife (Z) } \\
-0.26\end{array}$} & \multirow{2}{*}{$\begin{array}{r}\boldsymbol{p} \text {-value } \\
\\
0.40\end{array}$} \\
\hline & & 133 & (141) & 49 & $(51)$ & & & & & & \\
\hline-4 & 0.12 & 140 & (134) & 51 & (49) & 1.14 & 0.13 & 0.61 & 0.27 & -0.03 & 0.49 \\
\hline-3 & 0.03 & 132 & (142) & 48 & $(52)$ & 0.29 & 0.39 & -0.20 & 0.42 & -0.45 & 0.33 \\
\hline-2 & -0.13 & 117 & (157) & 43 & (57) & -1.17 & 0.12 & -1.90 & 0.03 & -1.67 & 0.05 \\
\hline-1 & 0.06 & 144 & (130) & 53 & (47) & 0.66 & 0.25 & 1.35 & 0.09 & 1.02 & 0.15 \\
\hline 0 & 0.22 & 155 & (119) & 57 & (43) & 2.31 & 0.01 & 2.49 & 0.01 & 2.49 & 0.01 \\
\hline 1 & 0.29 & 155 & (119) & 57 & (43) & 3.39 & 0.00 & 2.51 & 0.01 & 2.41 & 0.01 \\
\hline 2 & 0.04 & 135 & (139) & 49 & (51) & 0.44 & 0.33 & 0.43 & 0.33 & 0.48 & 0.32 \\
\hline 3 & 0.02 & 134 & (140) & 49 & (51) & 0.22 & 0.41 & 0.33 & 0.37 & -0.17 & 0.43 \\
\hline 4 & 0.00 & 133 & (141) & 49 & (51) & 0.01 & 0.50 & 0.17 & 0.43 & -0.08 & 0.47 \\
\hline 5 & -0.05 & 133 & (141) & 49 & (51) & -0.66 & 0.26 & -0.76 & 0.22 & -1.47 & 0.07 \\
\hline
\end{tabular}

Notes. PIP = Price-Increase Preannouncement; $\mathrm{N}=$ Number of observations pertaining to the outcome equation; AR $=$ Abnormal returns; CSectErr ( $\mathrm{t}$ ) $=$ CrossSectional Error t-statistic. The p-values are two-sided. Consistent with existing studies (e.g., Robinson et al., 2015), in determining the significance of the abnormal returns, we use a parametric test - the Cross-Sectional Error t-test (Brown \& Warner, 1985) - and two nonparametric tests - the Rank test (Corrado, 1989) and the Jackknife test (Giaccotto \& Sfiridis, 1996).

market (i.e., $R_{m t}$ in Eq. (1)), which already takes into account the macro-economic factors and the year-specific effects using overall stock-market returns (Flannery \& Protopapadakis, 2002). ${ }^{9}$

We outline the exclusion restrictions, their measures, data sources and examples of prior literature supporting the use of these measures in Table 2. In addition, we also describe how we arrive at the sample for the selection model in Web Appendix D.

\subsubsection{Addressing potential endogeneity}

Following recent event studies in marketing (e.g., Gielens et al., 2017), we adopt Park and Gupta's (2012) Gaussian copulas approach to account for the potential endogeneity of our expected continous variables. Specifically, we first assess the distribution of Time to Implementation, Magnitude, Own Precedence and Competitive Precedence to confirm the suitability of this method. Results from the Shapiro-Wilk test suggest that these variables are not normally distributed $\left(W_{\mathrm{TIME}_{\mathrm{ijt}}}=0.95, p<0.001 ; W_{\mathrm{MAG}_{\mathrm{ijt}}}=\right.$ $\left.0.98, p<0.001 ; W_{\mathrm{OWN}_{\mathrm{ijt}}}=0.97, p<0.001 ; W_{\mathrm{COMP}_{\mathrm{ijt}}}=0.92, p<0.001\right)$. In this way, the inclusion of the copula correction terms for these variables through a control function approach allows us to separate the variation due to these variables from that of the error term so that the effects of these variables can be estimated consistently (Papies, Ebbes, \& van Heerde, 2017). Following Park and Gupta (2012), we obtain the copula correction terms as follows:

$$
\begin{aligned}
& \operatorname{cop}\left(\operatorname{TIME}_{\mathrm{ijt}}\right)=\phi^{-1}\left(H\left(\mathrm{TIME}_{\mathrm{ijt}}\right)\right), \operatorname{cop}\left(\mathrm{MAG}_{\mathrm{ijt}}\right)=\phi^{-1}\left(H\left(\mathrm{MAG}_{\mathrm{ijt}}\right)\right) \\
& \operatorname{cop}\left(\mathrm{OWN}_{\mathrm{ijt}}\right)=\phi^{-1}\left(H\left(\mathrm{OWN}_{\mathrm{ijt}}\right)\right), \operatorname{cop}\left(\mathrm{COMP}_{\mathrm{ijt}}\right)=\phi^{-1}\left(H\left(\mathrm{COMP}_{\mathrm{ijt}}\right)\right)
\end{aligned}
$$

where $\phi^{-1}$ is the inverse of the cummulative normal distribution function, and $H\left(\mathrm{TIME}_{\mathrm{ijt}}\right), H\left(\mathrm{MAG}_{\mathrm{ijt}}\right), H\left(\mathrm{OWN}_{\mathrm{ijt}}\right)$ and $H\left(\mathrm{COMP}_{\mathrm{ijt}}\right)$ are the empirical distribution functions. These copula correction terms are first added one at a time to our model to test for their statistical significance. We only keep the statistically significant copula correction terms in our final model as the terms that are not statistically significant suggest that their corresponding variables are not endogeneous (Gielens et al., 2017; Park \& Gupta, 2012).

As the distribution of dummy variables is not suitable for the Gaussian copulas approach, we draw on an alternative procedure to address the potential endogeneity of Demand Attribution and Cost Attribution. Following recent studies in marketing (e.g., Clement et al., 2014), we assess the endogeneity of these variables using the Hausman-Wu test. In particular, we first estimate two auxiliary regressions using Demand Attribution and Cost Attribution as the dependent variables, along with the excluded variable and all other control variables that we include in our focal model.

Drawing on existing marketing studies that use lagged variables as exclusion restrictions (e.g., Albers, 2012), we use the attribution that the firm cites in its previous PIP as the excluded variable in both of the auxiliary regressions. We argue that the attribution that the firm cites in its previous PIP is a valid exclusion restriction because firms tend to adopt similar decision choices over a short time period such that if the firm cites a demand attribution in its previous PIP, it is likely to also cite a demand attribution in its current PIP. However, this excluded variable is unlikely to influence abnormal returns following the current

\footnotetext{
${ }^{9}$ To verify our exclusion restrictions, we estimated a model where the exclusion restrictions were included as additional control variables in the outcome equation Consistent with our expectations, we find that their joint effect on abnormal returns is not significant $\left(\chi^{2}(6)=6.85, p>0.10\right)$. 
PIP as the efficient-market hypothesis suggests that the stock price of the firm can only be influenced by the information provided in the firm's current PIP (MacKinlay, 1997). ${ }^{10}$

Upon obtaining the predicted values from the auxiliary regressions, we then include these values as instruments for Demand Attribution and Cost Attribution in our focal model using a stepwise approach. Each estimation is accompanied by a $\chi^{2}$-test to assess the statistical significance of the instruments. Results suggest that the potential endogeneity of Demand Attribution and Cost Attribution is not an issue, as we find that neither test is significant ( $p=0.36$ for Demand Attribution and $p=0.90$ for Cost Attribution).

\section{Results}

Table 3 reports the abnormal returns on the day of the PIP, as well as up to 5 days before and after the PIP. We use both a parametric test, the Cross-Sectional Error t-test (Brown \& Warner, 1985), and two nonparametric tests, the Rank test (Corrado, 1989) and the Jackknife test (Giaccotto \& Sfiridis, 1996), to test the significance of the abnormal returns.

Across the three tests, we find that the abnormal returns are most significant on day $t+1$, with a positive abnormal return of $0.29 \%(p<0.00)$. In addition, the cumulative average abnormal returns (CAAR) is most significant for the event window [0, 1 ]. Thus, we use the CAAR for the event window $[0,1]$ as the dependent variable to test the proposed expectations. We find that the CAAR for the event window $[0,1]$ is $0.51 \%$. However, there is wide variation in the CAARs. Almost $41 \%$ of the PIPs experience a negative CAAR. In terms of the range, while some PIPs yield returns as low as $-5.04 \%$, other PIPs result in positive returns as high as $15.59 \%$. Clearly, investors' evaluations differ considerably across PIPs.

Table 4 reports the estimation results (we refer to Web Appendix E, Table E1 for the descriptive statistics). The maximum VIF statistic of the model is 5.93, well below the threshold of 10 , suggesting that multicollinearity is not an issue for our model. We report one-sided significance levels for the parameter estimates of the directional expectations, and two-sided significance levels for all other parameter estimates.

We first discuss the results of our selection equation. The error correlation is not significant $(\rho=-0.20, p>0.10)$, indicating that selection bias is not a serious concern. We find support for the exclusion restrictions as we find that a higher percentage of institutional holdings results in a higher likelihood of making a PIP $\left(\delta_{16}=0.70, p<0.05\right)$. In addition, relative to 2010 , there is a lower likelihood of making a PIP in all subsequent years, except in $2011\left(\delta_{18}=-0.05, p>0.01 ; \delta_{19}=-0.56, p<0.01 ; \delta_{20}=\right.$ $\left.-0.77, p<0.01 ; \delta_{21}=-0.52, p<0.01\right)$. However, we find that firms' likelihood of making PIPs does not differ across different periods of economic growth $\left(\delta_{17}=0.02, p>0.10\right)$.

Consistent with our expectations, we find that greater time to implementation results in lower associated abnormal returns $\left(\gamma_{1}=-0.26, p<0.01\right)$, while a PIP citing demand attribution results in higher associated abnormal returns $\left(\gamma_{3}=\right.$ $0.36, p<0.05)$. In addition, we also find that higher own and competitive precedence result in lower associated abnormal returns $\left(\gamma_{5}=-0.29, p<0.05 ; \gamma_{6}=-0.22, p<0.05\right)$. With regards to the effect of magnitude on the associated abnormal returns, we find that results support the expectation of a positive impact $\left(\gamma_{2}=2.28, p<0.05\right)$. Finally, contrary to expectations, there is insufficient evidence to support our prediction that providing a cost attribution in a PIP results in lower associated abnormal returns $\left(\gamma_{4}=0.23, p>0.10\right)$.

\subsection{Sensitivity analyses}

We conducted several sensitivity analyses to assess the robustness of our conclusions. ${ }^{11}$

\subsubsection{Alternative dependent variables}

We examine the sensitivity of our results by using alternative methods to compute the dependent variable. First, we use the abnormal returns obtained from the estimation of two alternative models - the Fama and French (1993) three factor model and the market model (Brown \& Warner, 1985). Second, we also estimate the abnormal returns using an equally-weighted market-index. Finally, following Skiera, Bayer, and Schöler (2017, p.6), we examine the robustness of our results to the abnormal returns that account for only the value of the operating business. Our conclusions remain unchanged.

\subsubsection{Sensitivity to outliers}

Consistent with existing event studies in marketing (e.g., Robinson et al., 2015), we assess the impact of outliers by removing observations with residuals at the one percentile of each tail. We find the same results as in our focal analysis.

\subsubsection{Alternative standard errors}

We explore the sensitivity of our results to alternative computations of the standard errors in the following ways. First, to account for the possible correlation among multiple PIPs made by the same firm, we re-estimate the models by clustering the errors

\footnotetext{
10 The excluded variable for Demand (Cost) Attribution is measured as follows: $=1$ if the firm cites a demand (cost) attribution in its closest preceding PIP, $=0$ if the firm did not cite a demand (cost) attribution in its closest preceding PIP or did not make any previous PIPs from the start of our data. Importantly, the excluded variables were highly significant in the auxiliary regressions $\left(\chi^{2}(1)=11.85, p<0.001\right.$ for demand attribution exclusion; $\chi^{2}(1)=24.22, p<0.001$ for cost attribution exclusion), which testifies to the strength of the excluded variables.

11 An overview table and detailed estimation results on these robustness checks are provided in Web Appendix F.
} 
at the firm level. Second, we re-estimate a model with errors clustered at both the industry- and year-level to allow for possible correlation among PIPs made by different firms within the same industry in the same year. ${ }^{12}$ Third, we also re-estimate the models without the use of clustered standard errors, but using heteroscedasticity-robust standard errors (Wooldridge, 2009). Across the analyses, our conclusions remain unchanged.

\subsubsection{Alternative industry classification}

Given that the number of firms included in the selection sample might vary depending on the granularity of the NAICS codes utilized, we also consider an alternative industry classification, and repeat the estimation process using five-digit NAICS codes. Again, our substantive conclusions remain largely unchanged.

\subsubsection{Heckman two-step estimation}

We re-estimate our models using the more traditional Heckman (1979) two-step estimation technique. Our conclusions remain unchanged.

\subsubsection{Reputation of following through on PIPs}

Whether a firm followed through on its previous PIP could affect investors' evaluations of its subsequent PIPs. To that extent, we consider whether PIPs in our sample were preceded by announcements of a price increase retraction in the one year preceding its preannouncement date. Specifically, we checked whether there were news articles reporting that the firm was cancelling, delaying, or cutting back on a previously announced price increase, regardless of whether the announced price increase had eventually been implemented. We find that only 10 of the PIPs within our sample are preceded by such announcements. We re-estimated our model by first dropping these 10 PIPs. In addition, we estimated the model with an indicator variable for such an occurrence. In both instances, our conclusions remain unchanged, while the parameter of the indicator variable is not statistically significant $(p>0.10)$.

\subsubsection{Alternative measures}

We assess the robustness of our model to alternative measures. First, to account for the possibility that the PIP history of the firm and its competitors extend beyond a one-year period, we re-estimate our model using Own and Competitive Precedence measured over a two-year time window. Second, we also estimate our model using an alternative measure of Reputation. In particular, we use the corporate social performance data from the Kinder, Lydenberg, and Domini (KLD) Social Ratings Database as an alternative proxy for the firm's overall Reputation. The KLD database contains social ratings on how well a firm caters to issues like climate change, waste management, employee involvement, product safety, corruption and political instability, and financialsystem instability (MSCI ESG Research, 2015). Our conclusions remain unchanged.

\subsubsection{Alternative method to address selection bias}

The selection model specified in our focal analysis reflects a firm's decision to make a PIP on the condition that the PIPs provide information on time to implementation and magnitude. To account for a possible sample selection bias due to the lack of information on one, or both, of these variables, we specify a multinomial selection model to demonstrate an alternative decision structure. Specifically, the first-stage is a multinomial logit model that accounts for a firm's decision to make a PIP that provides information on time to implementation and magnitude $(\mathrm{n}=274)$, make a PIP with incomplete information (i.e., PIPs that do not provide information on either the time to implementation or the magnitude of the preannounced price increase or both; $\mathrm{n}=347$ ), or not make a PIP at all $(\mathrm{n}=3035)$.

Adopting the "conditional expectations correction method" as proposed by Dubin and McFadden (1984), we use the parameter estimates from the first-stage model to obtain the predicted conditional probabilities for each of the decision outcomes given the conditional probabilities of all other decision outcomes. These predicted conditional probabilities are then used to compute a set of correction terms to be included in the second-stage model to control for the possible sample selection bias. Following Bourguignon, Fournier, and Gurgand (2007), we include three correction terms to account for each of the three decision outcomes and bootstrap the second-stage regression (500 bootstrap replications) to account for the standard errors from the first-stage model.

Results show that our substantive conclusions remain unchanged if we use this approach. Importantly, none of the coefficients of the correction terms are statistically significant in the model (using a significance level of $p<0.10$ ), thus suggesting that sample selection bias is not a concern in this decision structure. Relatedly, given that we also do not find sufficient evidence to conclude that sample selection bias exists in the decision structure that we use in our focal analysis, we also re-estimate our model without accounting for sample selection bias. We again find that our results remain unchanged.

In addition, we also computed the abnormal returns following the PIPs with incomplete information using the event-study method. We find that the abnormal returns are not statistically significant on the day of the PIP, as well as up to 5 days before and after the PIP (for details, see Web Appendix F, Table F3). The CAAR for the event window $[0,1]$ is also not statistically significant $(-0.05 \%, p>0.10)$. This analysis suggests that investors respond to PIPs only when the firm provides investors with implementation information, i.e., the Time to Implementation and Magnitude, as they need this information to make an educated

\footnotetext{
12 To cluster the standard errors at both the industry- and year-level, we use a variable that contains a unique value for each industry-year pair, i.e., we create this variable by multiplying the firms' six-digit NAICS codes with the data year, and use this variable as the cluster variable (see Petersen, 2009 for a similar practice).
} 
estimate of the impact of a PIP on the change in future cash flows for the firm. PIPs with incomplete information do not significantly influence abnormal returns.

\subsubsection{Alternative method to address potential endogeneity}

We also explore the robustness of our results to alternative methods to deal with the potential endogeneity of some of our key drivers. As a first probe to assess the sensitivity of our results to the use of the copula approach, we dropped all such correction terms. We find that our results remain unchanged.

Second, we use instead Petrin and Train's (2010) two-stage control function approach. In a first-stage, we estimate an auxiliary regression with a given driver as dependent variable, and the control variables and an instrument as explanatory variables to obtain predicted residuals. Based on Germann, Ebbes, and Grewal (2015), we include the sector average value of a given driver as instrument. We identify a sector using a firm's three-digit NAICS code and compute the sector average values using the values of all the competing firms in the same sector, excluding that of the focal firm. In the second-stage, we re-estimate our focal model by including the predicted residuals from the first-stage to account for the potential endogeneity of the driver. Given that each of the main-effect variables can potentially be endogeneous, we estimate six auxiliary regressions in the first-stage to obtain six predicted residuals. Consistent with the empirical strategy of our focal analysis, we first assess the statistical significance of each of these predicted residual terms by adding them one at a time to our focal model. Since endogeneity is not a concern for variables in which their corresponding residual terms are not statistically significant (Imbens \& Wooldridge, 2007; Liu, Liu, \& Luo, 2016), we only retain the statistically significant residual terms in our final model to account for their potential endogeneity. Reassuringly, our substantive conclusions remain unchanged when using this control function approach.

\section{Discussion}

Firms regularly preannounce their price increases because it signals their ability to raise prices (Krishna, Feinberg, \& Zhang, 2007), provides timely information to customers and investors (Smith, 2011) and can act as a valuable competitive market signal (Prabhu \& Stewart, 2001). Existing research, however, offers neither a theoretical nor an empirical examination of how investors evaluate public announcements of future price increases. This study seeks to fill this void and has both theoretical and managerial implications.

\subsection{Theoretical implications}

By presenting a systematic examination of how investors evaluate PIPs, we respond to recent calls for a better understanding of investors' evaluations of firms' pricing actions (Edeling \& Fischer, 2016, p. 533). Results indicate that, on average, a PIP leads to positive abnormal returns of $0.51 \%$, i.e., an increase of $\$ 30.45$ million in a firm's market capitalization. ${ }^{13}$ This impact of a PIP is comparable to other marketing actions, such as the announcements of internet channel additions $(0.71 \%, £ 16.38$ million, per Geyskens et al., 2002) and brand licensing (0.33\%, \$37.52 million, per Robinson et al., 2015).

Interestingly, there is significant variation in investors' evaluations of a PIP with $41 \%$ of the PIPs resulting in negative abnormal returns. Accordingly, we built a conceptual framework to examine investors' evaluations of PIPs. Our study makes two valuable theoretical contributions to, respectively, the pricing and preannouncement literature.

First, we contribute to the pricing literature by examining investors' reactions toward price increases through their evaluations of PIPs. Extant research focused on customers' perceptions of price increases (e.g., Homburg et al., 2005; Homburg et al., 2010). By combining existing conclusions from the customer perspective with findings that reflect an economic and competitor perspective, we develop important new insights on the likely outcomes of price increases.

Second, we contribute to the preannouncement literature by highlighting the importance of time to implementation, attribution and precedence when communicating an upcoming price increase. We find that a PIP can result in lower abnormal returns as time to implementation increases. These results complement recent research in other domains, such as new product introductions (Sorescu et al., 2007) and product recalls (Eilert, Jayachandran, Kalaignanam, \& Swartz, 2017), that suggests that investors are likely to punish firms that delay the implementation of preannounced marketing actions.

Our findings also reveal that a PIP can result in higher abnormal returns if it features a demand attribution. However, in contrast to our expectations, citing a cost attribution does not significantly influence the impact of a PIP on abnormal returns. One probable explanation for this result might be that with respect to a firm's costs, investors value the actual financial information more than the information provided in the preannouncement. Indeed, in Table 4, we observe that the impact of a firm's reported COGS on abnormal returns is statistically significant $(p<0.01)$. Taken together, the findings on demand and cost attributions add to the literature on strategic preannouncements (e.g., Calantone \& Schatzel, 2000; Sorescu et al., 2007), as they identify when the provision of certain information is useful for investors.

\footnotetext{
${ }^{13}$ We obtain these figures by multiplying the abnormal returns with the average market capitalization of the firms in our sample.
} 


\subsection{Managerial implications}

Our results provide clear "univariate" guidelines for conditions under which investors are likely to appreciate (or not) PIPs. First, managers need to consider the importance of providing implementation information, i.e., time to implementation and magnitude of the planned price increase if they want investors to react. Indeed, investors do not respond to PIPs that do not provide this information. Second, managers should avoid making PIPs that have implementation dates too far into the future, as investors prefer PIPs with lower time to implementation. In contrast, managers are likely to derive more benefits from PIPs with higher (vs lower) magnitude. That said, managers are unlikely to receive any incremental benefits from extremely high price increases as compared to just high-magnitude PIPs. Third, the study points to the benefits of clear communication with investors as we find that investors reward PIPs where firms specifically mention rising demand as the underlying reason for a PIP. Finally, managers need to be prudent in terms of the frequency with which they make PIPs as investors' responses show a clear preference for PIPs that have lower precedence. In addition, managers need to be wary of being too much a follower, i.e., waiting for competitors to make a PIP before announcing their own PIP, as investors tend to punish firms that simply follow competitors in making PIPs.

The univariate guidelines provide a foundation to explore the different multi-faceted scenarios that managers are likely to face when considering making a PIP. Accordingly, we draw on prior work on retailer motivations behind price changes (e.g., Nijs, Srinivasan, \& Pauwels, 2007; Srinivasan, Pauwels, \& Nijs, 2008) to conduct counterfactual analyses to explore investors' evaluations of four pricing scenarios: demand-dominant, competitor driven, price sensitivity probing and cost-based (see Web Appendix G for details). ${ }^{14}$

\subsubsection{Demand-dominant}

A firm makes a PIP largely due to higher demand and the anticipation that customers will remain with it following its PIP in a demand-dominant pricing scenario. Given their confidence about the loyalty of their customers, firms are likely to make PIPs with low time to implementation and high magnitude. They are also likely to cite a demand-attribution in their PIPs to signal to investors their current operating circumstances, i.e., rising demand.

\subsubsection{Competitor driven}

Firms are likely to make PIPs in hopes that its competitors will follow its PIP and hence minimize its market share loss and other possible negative reactions from its customers. If competitors do not follow its PIP, the firm is unlikely to implement the preannounced price increase. Thus, firms in this pricing scenario are likely to make PIPs with moderate time to implementation to provide them with sufficient time to observe their competitors' reactions. Since it is important that the preannounced price increase is credible and is noticed by competitors, such PIPs are likely to have high magnitude. Finally, to avoid any suspicions of lawmakers due to concerns of price collusion, competitor driven PIPs are likely to have low own and competitive precedence.

\subsubsection{Price sensitivity probing}

When firms are unable to anticipate customers' reactions toward their price increase, they are likely to adopt the price sensitivity probing scenario to assess customers' reactions. As such, in this scenario, the firm is likely to have a high time to implementation as it allows them to see whether customers react strongly (or not) to the PIP, and whether competitors are likely to follow the firm. Given the importance of assessing competitors' reactions, firms facing high competitive precedence are more likely to do this.

\subsubsection{Cost-based}

In the cost-based pricing scenario, a firm makes a PIP because its costs are rising, and it feels the need to pass them on to customers. This pricing scenario is likely to feature firms that make PIPs with a cost attribution to signal to investors its rising costs.

As shown in Table 5, across the four pricing scenarios, investors are likely to evaluate PIPs made in the demand-dominant pricing scenario most favorably $(1.91 \%, p<0.01)$ followed by competitor driven $\operatorname{PIPs}(1.83 \%, p<0.01)$. Interestingly, both the price sensitivity probing $(-0.32 \%, p>0.10)$ and the cost-based $(-0.07 \%, p>0.10)$ PIPs are likely to yield insignificant abnormal returns. Managers are therefore encouraged to consider making a preannouncement of an upcoming price increase when confronted with a demanddominant or competitor driven scenario. In dollar terms, PIPs in the demand-dominant scenario are likely to increase the market capitalization of an "average" firm, based on figures from a recent report (CRSP, 2018), by \$145 million, whereas the ones that are competitor driven are likely to have an impact of $\$ 139$ million.

Results for price sensitivity probing and the cost-based scenarios suggest that managers making PIPs under these scenarios should not expect a significant reaction from investors. The reason is that both these scenarios present investors with opposing signals. Specifically, in the price sensitivity probing scenario, the positive effects of the magnitude of a PIP are countered by the high levels of time to implementation and competitive precedence. Similarly, the articulation of a cost-based attribution for the PIP signals that any potential benefits due to the potential increase in price are likely to be negated due to rising costs. Taken together, the results of the counterfactual analyses underscore the importance of jointly considering the factors proposed in current study and identify the demand-dominant and competitor driven settings as the two scenarios that investors are likely to reward.

${ }^{14}$ We are indebted to the Senior Editor for his/her valuable input in this classification. 


\subsection{Limitations and future research}

Results of the current study should be interpreted in light of its limitations, some of which provide opportunities for future research. First, future research can complement this study by examining the effect of PIPs on various operational metrics, such as changes in sales revenues following the PIP or changes in the penetration and/or purchase frequency of the products involved in the PIP.

Table 4

Factors predicting abnormal returns.

\begin{tabular}{|c|c|c|c|}
\hline EXP & Outcome model & Coeff & (SE) \\
\hline- & Time to implementation & -0.26 & $(0.11)^{\dagger \dagger \dagger}$ \\
\hline$?$ & Magnitude & 2.28 & $(1.12)^{* *}$ \\
\hline+ & Demand attribution & 0.36 & $(0.21)^{\dagger \dagger}$ \\
\hline- & Cost attribution & 0.23 & $(0.23)$ \\
\hline- & Own precedence & -0.29 & $(0.14)^{\dagger \dagger}$ \\
\hline- & Competitive precedence & -0.22 & $(0.13)^{\dagger+}$ \\
\hline \multicolumn{4}{|c|}{ Firm-level controls } \\
\hline & Spokesperson & -0.08 & $(0.21)$ \\
\hline & Reputation & 0.09 & $(0.35)$ \\
\hline & Corporate branding & -0.32 & $(0.30)$ \\
\hline & Cash flows & -0.66 & $(3.74)$ \\
\hline & ROA & 7.55 & $(3.68)^{* *}$ \\
\hline & Leverage & 0.27 & $(0.29)$ \\
\hline & Liquidity & 0.03 & $(0.14)$ \\
\hline & Firm size & -0.14 & $(0.14)$ \\
\hline & COGS & 4.46 & $(1.26)^{* * *}$ \\
\hline & Capital intensity & -0.11 & $(1.11)$ \\
\hline \multicolumn{4}{|c|}{ Industry-level controls } \\
\hline & Number of firms & 0.42 & $(0.28)$ \\
\hline & Industry concentration & 0.63 & $(0.88)$ \\
\hline & Industry growth & 0.03 & $(1.62)$ \\
\hline & Industry turbulence & 1.04 & $(1.24)$ \\
\hline & Service industry & -0.38 & $(0.49)$ \\
\hline & Business-to-consumer & -0.46 & $(0.39)$ \\
\hline \multicolumn{4}{|c|}{ Copula correction terms ${ }^{a}$} \\
\hline & $\begin{array}{l}\text { Copula correction term } \\
\text { for magnitude }\end{array}$ & -1.09 & $(0.66)^{*}$ \\
\hline \multirow[t]{2}{*}{ Constant } & & -6.93 & $(2.78)^{* *}$ \\
\hline & Selection model & Coeff & (SE) \\
\hline \multicolumn{4}{|c|}{ Firm-level controls } \\
\hline & Reputation & 0.14 & $(0.25)$ \\
\hline & Corporate branding & -0.27 & $(0.23)$ \\
\hline & Cash Flows & 1.68 & $(1.54)$ \\
\hline & ROA & -3.04 & $(1.25)^{* *}$ \\
\hline & Leverage & -0.15 & $(0.09)$ \\
\hline & Liquidity & 0.07 & $(0.06)$ \\
\hline & Firm Size & 0.42 & $(0.08)^{* * *}$ \\
\hline & COGS & 0.04 & $(0.19)$ \\
\hline & Capital intensity & 2.09 & $(0.76)^{* * *}$ \\
\hline \multicolumn{4}{|c|}{ Industry-level controls } \\
\hline & Number of firms & -0.48 & $(0.13)^{* * *}$ \\
\hline & Industry concentration & -0.83 & $(0.62)$ \\
\hline & Industry growth & 0.25 & $(0.95)$ \\
\hline & Industry turbulence & 1.23 & $(1.00)$ \\
\hline & Service industry & -0.33 & $(0.35)$ \\
\hline & Business-to-consumer & -0.41 & $(0.22)^{*}$ \\
\hline \multicolumn{4}{|c|}{ Exclusion restrictions } \\
\hline & Percentage of institutional holdings & 0.70 & $(0.29)^{* *}$ \\
\hline & Economic growth & 0.02 & $(0.03)$ \\
\hline & Year dummy 1: 2011 & -0.05 & $(0.13)$ \\
\hline & Year dummy 2: 2012 & -0.56 & $(0.17)^{* * *}$ \\
\hline & Year dummy 3: 2013 & -0.77 & $(0.21)^{* * *}$ \\
\hline & Year dummy 4: 2014 & -0.52 & $(0.19)^{* * *}$ \\
\hline \multirow[t]{5}{*}{ Constant } & & -3.21 & $(1.18)^{* * *}$ \\
\hline & $\rho$ & -0.20 & $(0.18)$ \\
\hline & Wald Chi-Square (df) & $79.46(23)^{* * * *}$ & \\
\hline & Maximum VIF & 5.93 & \\
\hline & $\mathrm{R}^{2}$ & $0.15^{* * *}$ & \\
\hline
\end{tabular}


Table 5

Results of counterfactual analyses across four pricing scenarios.

\begin{tabular}{|c|c|c|c|c|}
\hline \multirow[b]{2}{*}{ Expected effects } & \multicolumn{4}{|l|}{ Pricing scenarios } \\
\hline & Demand-dominant & $\begin{array}{l}\text { Competitor } \\
\text { driven }\end{array}$ & $\begin{array}{l}\text { Price sensitivity } \\
\text { probing }\end{array}$ & Cost-based \\
\hline Time to implementation & Low & Moderate & High & High \\
\hline Magnitude & High & High & Low & Low \\
\hline Attribution & Demand & Actual & Actual & Cost \\
\hline Own precedence & Actual & Low & Actual & Actual \\
\hline Competitive precedence & Actual & Low & High & Actual \\
\hline Predicted abnormal returns (in \%) & $1.91^{* * *}$ & $1.83^{* * * *}$ & -0.32 & -0.07 \\
\hline
\end{tabular}

Notes. Actual = Actual values of the corresponding variable; Low $=25$ th percentile value of the distribution of the corresponding variable; High $=75$ th percentile value of the distribution of the corresponding variable; Moderate = Median value of the distribution of the corresponding variable. The technical details on the counterfactual analyses are presented in Web Appendix G.

*** $p<0.01$ (two-sided).

Second, since the focus of this study is on the abnormal returns in the event window surrounding the PIP, the realized long-run value of the preannounced price increase is not discernible in our findings. Following the PIP, investors' might dynamically alter their evaluations after observing the subsequent reactions of competitors and customers. These reactions might even cause the firm to retract the preannounced price increase. Although we do take into account prior announcements of price retraction in our sensitivity analyses, these announcements may act more like reputation builders for investors. Thus, more research is required to examine the long-run effects of a PIP.

Third, even though event studies are quasi-experiments (Srinivasan \& Hanssens, 2009), it is important to keep in mind that we use cross-sectional data. As such, readers should be cautious in drawing too strong causal implications from this study.

Fourth, as this study focuses on understanding, both theoretically and empirically, investors' evaluations of PIPs, we did not elaborate on firms' motivations for making PIPs. More research is required to also examine the reasons why some firms preannounce price changes and/or provide information on the specific time to implementation and size of the price increase in the preannouncement while others don't.

Finally, in our counterfactual analyses, we focused on four frequently occurring pricing scenarios. However, additional insights may well be obtained by also exploring other level combinations of the focal PIP drivers.

\section{Web Appendices}

The web appendices for this article can be found online at https://doi.org/10.1016/j.ijresmar.2018.06.001.

\section{References}

Albers, S. (2012). Optimizable and implementable aggregate response modeling for marketing decision support. International Journal of Research in Marketing, 29(2), $111-122$.

Anderson, E., Jaimovich, N., \& Simester, D. (2015). Price stickiness: Empirical evidence of the menu cost channel. The Review of Economics and Statistics, 97(4), 813-826. Ausick, P. (2014). "Prices rising for Starbucks coffee," Yahoo! Finance, (June 20). available at http://finance.yahoo.com/news/prices-rising-starbucks-coffee193646126.html, Accessed date: 27 February 2016.

Bahadir, S. C., Bharadwaj, S. G., \& Srivastava, R. K. (2008). Financial value of Brands in Mergers and Acquisitions: Is value in the eye of the beholder? Journal of Marketing, 72(6), 49-64.

Baker, W. L., Marn, M. V., \& Zawada, C. C. (2010). “Building a better pricing infrastructure,” McKinsey \& Company, (August 10). available at http://www.mckinsey.com/ business-functions/marketing-and-sales/our-insights/building-a-better-pricing-infrastructure, Accessed date: 27 February 2016.

Bharadwaj, S. G., Tuli, K. R., \& Bonfrer, A. (2011). The impact of brand quality on shareholder wealth. Journal of Marketing, 75(5), 88-104.

Bijmolt, T. H. A., van Heerde, H. J., \& Pieters, R. G. M. (2005). New empirical generalizations on the determinants of price elasticity. Journal of Marketing Research, 42(2), $141-156$.

Bolton, L. E., Warlop, L., \& Alba, J. W. (2003). Consumer perceptions of price (un)fairness. Journal of Consumer Research, 29(4), 474-491.

Bourguignon, F., Fournier, M., \& Gurgand, M. (2007). Selection Bias corrections based on the multinomial logit model: Monte Carlo comparisons. Journal of Economic Surveys, 21(1), 174-205.

Breen, R. (1996). Regression models: Censored, sample selected, or truncated data. London: Sage Publications.

Brown, S. J., \& Warner, J. B. (1985). Using daily stock returns: The case of event studies. Journal of Financial Economics, 14(1), 3-31.

Notes to Table 4:

Notes. ROA = Return on Assets; COGS = Cost of Goods Sold; EXP = Expected Effects; Coeff = Coefficient; SE = Standard Error; df = Degrees of Freedom; Maximum $\mathrm{VIF}=$ Highest variance inflation factor of the outcome equation; $\mathrm{R}^{2}=\mathrm{R}$-squared value of the outcome equation. There are 274 ( 2473 ) observations pertaining to the outcome (selection) equation. We Winsorize all continuous variables at the 1st and 99th percentile levels. We allow the error terms within a given six-digit North American Industry Classification System to be correlated with each other.

† $p<0.05$.

${ }^{+1+} p<0.01$ (one-sided).

$* p<0.10$,

** $p<00.05$,

*** $p<0.01$ (two-sided)

a We do not include the copula correction terms for Time to Implementation, Own and Competitive Precedence in the final model as they were not statistically significant when we included them in our preliminary (one variable at a time) endogeneity testing (i.e., $p=0.71, p=0.38, p=0.27$ respectively). 
Bruno, H. A., Che, H., \& Dutta, S. (2012). Role of reference price on price and quantity: Insights from business-to-business markets. Journal of Marketing Research, 49(5), $640-654$.

Burnham, T. A., Frels, J. K., \& Mahajan, V. (2003). Consumer switching costs: A typology, antecedents, and consequences. Journal of the Academy of Marketing Science, 31 (2), 109.

Bushee, B. J., \& Noe, C. F. (2000). Corporate disclosure practices, institutional investors, and stock return volatility. Journal of Accounting Research, 38, 171-202.

Calantone, R. J., \& Schatzel, K. E. (2000). Strategic foretelling: Communication-based antecedents of a Firm's propensity to preannounce. Journal of Marketing, 64(1), 17-30.

Campbell, M. C. (1999). Perceptions of price unfairness: Antecedents and consequences. Journal of Marketing Research, 36(2), 187-199.

Campbell, M. C. (2007). "Says who?!" how the source of price information and affect influence perceived price (un)fairness. Journal of Marketing Research, 44(2), 261-271.

Carhart, M. M. (1997). On persistence in mutual fund performance. The Journal of Finance, 52(1), 57-82.

Clement, M., Wu, S., \& Fischer, M. (2014). Empirical generalizations of demand and supply dynamics for movies. International Journal of Research in Marketing, 31(2), 207-223.

Corrado, C. J. (1989). A nonparametric test for abnormal security-price performance in event studies. Journal of Financial Economics, 23(2), 385-395.

Coval, J. D., \& Moskowitz, T. J. (1999). Home Bias at home: Local equity preference in domestic portfolios. The Journal of Finance, 54(6), 2045-2073.

CRSP (2018). "Quarterly performance U.S. total market cap index," CRSP Indexes, (March 29, 2018). available at http://www.crsp.com/files/crsptm1_quarterly_reportmarch2018.pdf, Accessed date: 18 June 2018.

Deleersnyder, B., Dekimpe, M. G., Sarvary, M., \& Parker, P. M. (2004). Weathering tight economic times: The sales evolution of consumer durables over the business cycle. Quantitative Marketing and Economics, 2(4), 347-383.

DelVecchio, D., Shanker Krishnan, H., \& Smith, D. C. (2007). Cents or percent? The effects of promotion framing on price expectations and choice. Journal of Marketing, 71(3), 158-170.

Dubin, J. A., \& McFadden, D. L. (1984). An econometric analysis of residential electric appliance holdings and consumption. Econometrica, 52(2), 345-362.

Edeling, A., \& Fischer, M. (2016). Marketing's impact on firm value: Generalizations from a meta-analysis. Journal of Marketing Research, 53(4), 515-534.

Eilert, M., Jayachandran, S., Kalaignanam, K., \& Swartz, T. A. (2017). Does it pay to recall your product early? An empirical investigation in the automobile industry. Journal of Marketing, 81(3), 111-129.

Eliashberg, J., \& Robertson, T. S. (1988). New product preannouncing behavior: A market signaling study. Journal of Marketing Research, 25 (3), $282-292$.

Erdem, T., \& Keane, M. P. (1996). Decision-making under uncertainty: Capturing dynamic brand choice processes in turbulent consumer goods markets. Marketing Science, 15(1), 1-20.

Fama, E. F. (1991). Efficient capital markets: II. The Journal of Finance, 46(5), 1575-1617.

Fama, E. F. \& French, K. R. (1993). Common risk factors in the returns on stocks and bonds. Journal of Financial Economics, 33(1), 3-56.

Fang, E., Palmatier, R. W., \& Grewal, R. (2011). Effects of customer and innovation asset configuration strategies on firm performance. Journal of Marketing Research, 48 (3), 587-602.

Fang, E., Palmatier, R. W., \& Steenkamp, J. -B. E. M. (2008). Effect of service transition strategies on firm value. Journal of Marketing, 72(5), 1-14.

Flannery, M. J., \& Protopapadakis, A. A. (2002). Macroeconomic factors do influence aggregate stock returns. Review of Financial Studies, 15 (3), 751-782.

Frye, A., \& Campbell, D. (2011). "Buffett says pricing power more important than good management," Bloomberg Business, (February 18). available at http://www. bloomberg.com/news/articles/2011-02-18/buffett-says-pricing-power-more-important-than-good-management, Accessed date: 27 February 2016.

Germann, F., Ebbes, P., \& Grewal, R. (2015). The chief marketing officer matters! Journal of Marketing, 79(3), 1-22.

Geyskens, I., Gielens, K., \& Dekimpe, M. G. (2002). The market valuation of Internet Channel additions. Journal of Marketing, 66(2), 102-119.

Giaccotto, C., \& Sfiridis, J. M. (1996). Hypothesis testing in event studies: The case of variance changes. Journal of Economics and Business, 48(4), 349-370.

Gielens, Katrijn, Inge Geyskens, Barbara Deleersnyder, Max Nohe (2017), "The new regulator in town: The effect of Walmart's sustainability mandate on supplier shareholder value," Journal of Marketing, In-Press.

Grewal, R., Chandrashekaran, M., \& Citrin, A. V. (2010). Customer satisfaction heterogeneity and shareholder value. Journal of Marketing Research, 47(4), 612-626.

Gruca, T. S., \& Rego, L. L. (2005). Customer satisfaction, cash flow, and shareholder value. Journal of Marketing, 69(3), 1-130.

Hamilton, B. H., \& Nickerson, J. A. (2003). Correcting for endogeneity in strategic management research. Strategic Organization, 1(1), 51-78.

Hayes, R., \& Singh, R. (2013). “Pricing for profitability: What's in your pocket?,” Deloitte University Press, CFO Insights Strategy, (August 2). available at http://dupress. com/articles/pricing-profitability-whats-pocket/\#, Accessed date: 27 February 2016.

Heckman, J. J. (1979). Sample selection Bias as a specification error. Econometrica, 47(1), 153-161.

Heil, O. P., \& Langvardt, A. W. (1994). The Interface between competitive market signaling and antitrust law. Journal of Marketing, 58(3), 81-96.

Hellofs, L. L., \& Jacobson, R. (1999). Market share and Customers' perceptions of quality: When can firms grow their way to higher versus lower quality? Journal of Marketing, 63(1), 16-25.

Homburg, C., Hoyer, W. D., \& Koschate, N. (2005). Customers' reactions to price increases: Do customer satisfaction and perceived motive fairness matter? Journal of the Academy of Marketing Science, 33(1), 36

Homburg, C., Koschate, N., \& Totzek, D. (2010). How price increases affect future purchases: The role of mental budgeting, income, and framing. Psychology and Marketing, 27(1), 36-53.

Homburg, C., Vollmayr, J., \& Hahn, A. (2014). Firm value creation through Major Channel expansions: Evidence from an event study in the United States, Germany, and China. Journal of Marketing, 78(3), 38-61.

Hsu, L., \& Lawrence, B. (2016). The role of social media and brand equity during a product recall crisis: A shareholder value perspective. International Journal of Research in Marketing, 33(1), 59-77.

Imbens, G. W., \& Wooldridge, J. M. (2007). Control function and related methods. Lecture Note 6, Nber Summer Institute, July 31. Cambridge, MA: National Bureau of Economic Research.

J.M. Smucker Company (2011). “The J. M. Smucker Company announces coffee price increases,” Investor Relations, (February 8). available at http://www.jmsmucker. com/investor-relations/smuckers-financial-news-releases/article/1526225, Accessed date: 25 January 2018.

Kalaignanam, K., \& Cem Bahadir, S. (2013). Corporate brand name changes and business restructuring: Is the relationship complementary or substitutive? Journal of the Academy of Marketing Science, 41(4), 456-472

Kalyanaram, G., \& Winer, R. S. (1995). Empirical generalizations from reference price research. Marketing Science, 14(3_supplement) (G161-G69).

Kavilanz, P. (2013). "Starbucks to raise prices for coffee drinks," CNN Money, (June 21, 2013). available at http://money.cnn.com/2013/06/21/news/companies/ starbucks/index.html, Accessed date: 1 January 2018.

Keil, S. K., Reibstein, D., \& Wittink, D. R. (2001). The impact of business objectives and the time horizon of performance evaluation on pricing behavior. International Journal of Research in Marketing, 18(1-2), 67-81.

Kohli, C. (1999). Signaling new product introductions: A framework explaining the timing of preannouncements. Journal of Business Research, 46(1), 45-56.

Koschate-Fischer, N., Cramer, J., \& Hoyer, W. D. (2014). Moderating effects of the relationship between private label share and store loyalty. Journal of Marketing, 78(2), 69-82.

Krishna, A., Feinberg, F. M., \& Zhang, J. (2007). Should price increases be targeted?-Pricing power and selective vs. across-the-board price increases. Management Science, 53(9), 1407-1422.

Kwak, H., Puzakova, M., \& Rocereto, J. F. (2015). Better not smile at the price: The differential role of brand Anthropomorphization on perceived price fairness. Journal of Marketing, 79(4), 56-76.

Larkin, Y. (2013). Brand perception, cash flow stability, and financial policy. Journal of Financial Economics, 110(1), 232-253.

Lee, R. P., \& Grewal, R. (2004). Strategic responses to new technologies and their impact on firm performance. Journal of Marketing, 68(4), 157-171.

Liu, A. X., Liu, Y., \& Luo, T. (2016). What drives a Firm's choice of product recall remedy? The impact of remedy cost, product hazard, and the Ceo. Journal of Marketing, $80(3), 79-95$

Luo, X. (2007). Consumer negative voice and firm-idiosyncratic stock returns. Journal of Marketing, 71(3), 75-88. 
Luo, X., \& Homburg, C. (2007). Neglected outcomes of customer satisfaction. Journal of Marketing, 71(2), 133-149.

Luo, X., \& Homburg, C. (2008). Satisfaction, complaint, and the stock value gap. Journal of Marketing, 72(4), 29-43.

Luo, X., Homburg, C., \& Wieseke, J. (2010). Customer satisfaction, analyst stock recommendations, and firm value. Journal of Marketing Research, 47(6), 1041-1058.

MacKinlay, A. C. (1997). Event studies in economics and finance. Journal of Economic Literature, 35(1), 13-39.

Malshe, A., \& Agarwal, M. K. (2015). From finance to marketing: The impact of financial leverage on customer satisfaction. Journal of Marketing, 79(5), 21-38.

Marn, M. V., Roegner, E. V., \& Zawada, C. C. (2004). The price advantage. John Wiley \& Sons.

McAlister, L., Srinivasan, R., Jindal, N., \& Cannella, A. A. (2016). Advertising effectiveness: The moderating effect of firm strategy. Journal of Marketing Research, 53(2), 207-224.

Meehan, J., Davenport, C., \& Kahlon, S. (2012). The price of pricing effectiveness: Is the view worth the climb? Deloitte Review. 11. (pp. 18-29). Deloitte University Press.

Mishra, S., \& Modi, S. B. (2016). Corporate social responsibility and shareholder wealth: The role of marketing capability. Journal of Marketing, 80(1), 26-46.

Mittal, V., Anderson, E. W., Sayrak, A., \& Tadikamalla, P. (2005). Dual emphasis and the long-term financial impact of customer satisfaction. Marketing Science, 24(4), 544-555.

Montgomery, D. B., Moore, M. C., \& Urbany, J. E. (2005). Reasoning about competitive reactions: Evidence from executives. Marketing Science, 24(1), 138-149.

Morgan, N. A., \& Rego, L. L. (2009). Brand portfolio strategy and firm performance. Journal of Marketing, 73(1), 59-74.

MSCI ESG Research (2015). “Msci Esg Kld Stats: 1991-2014 data sets methodology,” (June 2015). available at https://wrds-web.wharton.upenn.edu/wrds/support/ Data/_001Manuals\%20and\%200verviews/_070KLD/_001General/_001MSCI\%20ESG\%20KLD\%20STATS\%20Methodology\%20-\%201991-2014.pdf.cfm, Accessed date: 4 January 2017.

Nachum, L., \& Zaheer, S. (2005). The persistence of distance? The impact of technology on Mne motivations for foreign investment. Strategic Management Journal, 26 (8), 747-767.

Nagel, S. (2005). Short sales, institutional investors and the cross-section of stock returns. Journal of Financial Economics, 78(2), 277-309.

Nijs, V. R., Dekimpe, M. G., Steenkamps, J. -B. E. M., \& Hanssens, D. M. (2001). The category-demand effects of price promotions. Marketing Science, 20(1), 1-22.

Nijs, V. R., Srinivasan, S., \& Pauwels, K. (2007). Retail-price drivers and retailer profits. Marketing Science, 26(4), 473-487.

Papies, D., Ebbes, P., \& van Heerde, H. J. (2017). Addressing endogeneity in marketing models. In P. S. H. Leeflang, J. E. Wieringa, T. H. A. Bijmolt, \& K. H. Pauwels (Eds.), Advanced methods for modeling markets. Springer.

Park, S., \& Gupta, S. (2012). Handling endogenous Regressors by joint estimation using copulas. Marketing Science, 31(4), 567-586.

Pauwels, K., Srinivasan, S., \& Franses, P. H. (2007). When do price thresholds matter in retail categories? Marketing Science, 26(1), 83-100.

Petersen, M. A. (2009). Estimating standard errors in finance panel data sets: Comparing approaches. Review of Financial Studies, 22(1), 435-480,

Petrin, A., \& Train, K. (2010). A control function approach to endogeneity in consumer choice models. Journal of Marketing Research, 47(1), 3-13.

Prabhu, J., \& Stewart, D. W. (2001). Signaling strategies in competitive interaction: Building reputations and hiding the truth. Journal of Marketing Research, 38(1), $62-72$.

Prushan, V. H. (1997). Price leadership issues. No-nonsense marketing: 101 practical ways to win and keep customers (pp. 145). Canada: John Wiley \& Sons.

Rajendran, K. N., \& Tellis, G. J. (1994). Contextual and temporal components of reference price. Journal of Marketing, 58(1), 22-34.

Ramaswamy, V., Desarbo, W. S., Reibstein, D. J., \& Robinson, W. T. (1993). An empirical pooling approach for estimating marketing mix elasticities with Pims data. Marketing Science, 12(1), 103-124.

Ramaswamy, V., Gatignon, H., \& Reibstein, D. J. (1994). Competitive marketing behavior in industrial markets. Journal of Marketing, 58(2), 45-55.

Rao, A. R. (2005). The quality of price as a quality cue. Journal of Marketing Research, 42(4), 401-405.

Rao, V. R., Agarwal, M. K., \& Dahlhoff, D. (2004). How is manifest branding strategy related to the intangible value of a corporation? Journal of Marketing, 68(4), $126-141$.

Ratchford, B. T. (2009). Consumer search and pricing. In V. R. Rao (Ed.), Handbook of pricing research in marketing (pp. 91-107). Massachusetts: Edward Elgar Publishing Inc.

Robinson, A. B., Tuli, K. R., \& Kohli, A. K. (2015). Does brand licensing increase a Licensor's shareholder value? Management Science, 61(6), 1436-1455.

Rubera, G., \& Kirca, A. H. (2012). Firm innovativeness and its performance outcomes: A meta-analytic review and theoretical integration. Journal of Marketing, 76(3), $130-147$.

Rust, R. T., \& Huang, M. -H. (2012). Optimizing service productivity. Journal of Marketing, 76(2), 47-66.

Rust, R. T., Moorman, C., \& Dickson, P. R. (2002). Getting return on quality: Revenue expansion, cost reduction, or both? Journal of Marketing, 66(4), 7-24.

Skiera, B., Bayer, E., \& Schöler, L. (2017). What should be the dependent variable in marketing-related event studies? International Journal of Research in Marketing, 34(3), 641-659.

Smith, T. (2011). Competition and pricing. Pricing strategy: Setting price levels, managing price discounts and establishing price structures (pp. 282-283). Nelson Education.

Sorescu, A., Shankar, V., \& Kushwaha, T. (2007). New product preannouncements and shareholder value: Don't make promises you Can't keep. Journal of Marketing Research, 44(3), 468-489.

Srinivasan, R., \& Bharadwaj, S. (2004). Event studies in marketing research. In C. Moorman, \& D. R. Lehmann (Eds.), Assessing marketing strategy performance (pp. 9-28). Cambridge, MA: Marketing Science Institute.

Srinivasan, S., \& Hanssens, D. M. (2009). Marketing and firm value: Metrics, methods, findings, and future directions. Journal of Marketing Research, 46(3), 293-312.

Srinivasan, S., Pauwels, K., \& Nijs, V. (2008). Demand-based pricing versus past-price dependence: A cost-benefit analysis. Journal of Marketing, 72(2), 15-27.

Srinivasan, S., Pauwels, K., Silva-Risso, J., \& Hanssens, D. M. (2009). Product innovations, advertising, and stock returns. Journal of Marketing, 73(1), $24-43$.

Srivastava, R. K., Shervani, T. A., \& Fahey, L. (1998). Market-based assets and shareholder value: A framework for analysis. Journal of Marketing, 62(1), 2-18.

Srivastava, R. K., Shervani, T. A., \& Fahey, L. (1999). Marketing, business processes, and shareholder value: An organizationally embedded view of marketing activities and the discipline of marketing. Journal of Marketing, 63, 168-179.

Subhedar, V., \& Rees, K. (2017). "Rpt-investment focus-return of inflation puts focus on pricing power," Reuters, (January 16). available at http://www.reuters.com/ article/europe-stocks-inflation-idUSL5N1F6255, Accessed date: 19 January 2017.

Thomadsen, R. (2012). Seeking an expanding competitor: How product line expansion can increase all firms' profits. Journal of Marketing Research, 49(3), 349-360.

Vomberg, A., Homburg, C., \& Bornemann, T. (2015). Talented people and strong brands: The contribution of human capital and brand equity to firm value. Strategic Management Journal, 36(13), 2122-2131.

Wang, R., Saboo, A. R., \& Grewal, R. (2015). A managerial capital perspective on chief marketing officer succession. International Journal of Research in Marketing, 32(2), $164-178$.

Warren, N. L., \& Sorescu, A. (2017). Interpreting the stock returns to new product announcements: How the past shapes Investors' expectations of the future. Journal of Marketing Research, 54(5), 799-815.

Wooldridge, J. M. (2009). Mason, OH: South Western, Cengage Learning.

Xia, L., Monroe, K. B., \& Cox, J. L. (2004). The price is unfair! A conceptual framework of price fairness perceptions. Journal of Marketing, 68(4), 1-15.

Ziobro, P. (2011). "Smucker raising prices on Jif Peanut Butter, fruit spreads," Dow Jones newswires, (September 8). available at https://global-factiva-com.libproxy. smu.edu.sg/redir/default.aspx?P=sa\&an=DJ00000020110907e797000it\&cat=a\&ep=ASE, Accessed date: 25 January 2018. 